\title{
New insights into the organic carbon export in the Mediterranean Sea from 3-D modeling
}

\author{
A. Guyennon ${ }^{1}$, M. Baklouti ${ }^{1}$, F. Diaz ${ }^{1}$, J. Palmieri ${ }^{2}$, J. Beuvier ${ }^{3,4}$, C. Lebaupin-Brossier ${ }^{4}$, T. Arsouze ${ }^{5,6}$, K. Béranger ${ }^{5}$, \\ J.-C. Dutay ${ }^{7}$, and T. Moutin ${ }^{1}$ \\ ${ }^{1}$ Aix Marseille Université, CNRS/INSU, Université de Toulon, IRD, Mediterranean Institute of Oceanography (MIO) \\ UM110, 13288, Marseille, France \\ ${ }^{2}$ Southampton University - National Oceanography Centre (NOC), Waterfront Campus, European Way, \\ Southampton SO14 3ZH, UK \\ ${ }^{3}$ Mercator Ocean, Ramonville Saint-Agne, France \\ ${ }^{4}$ CNRM-GAME, Météo-France/CNRS, Toulouse, France \\ ${ }^{5}$ UME, ENSTA-ParisTech, Palaiseau, France \\ ${ }^{6}$ Laboratoire de Météorologie Dynamique, École Polytechnique, Palaiseau, France \\ ${ }^{7}$ LSCE/IPSL, Laboratoire des Sciences du Climat et de l'Environnement, CEA-CNRS-UVSQ, Gif-sur-Yvette, France
}

Correspondence to: M. Baklouti (melika.baklouti@mio.osupytheas.fr)

Received: 12 March 2015 - Published in Biogeosciences Discuss.: 24 April 2015

Revised: 27 October 2015 - Accepted: 5 November 2015 - Published: 7 December 2015

\begin{abstract}
The Mediterranean Sea is one of the most oligotrophic regions of the oceans, and nutrients have been shown to limit both phytoplankton and bacterial activities, resulting in a potential major role of dissolved organic carbon (DOC) export in the biological pump. Strong DOC accumulation in surface waters is already well documented, though measurements of DOC stocks and export flux are still sparse and associated with major uncertainties. This study provides the first basin-scale overview and analysis of organic carbon stocks and export fluxes in the Mediterranean Sea through a modeling approach based on a coupled model combining a mechanistic biogeochemical model (Eco3MMED) and a high-resolution (eddy-resolving) hydrodynamic simulation (NEMO-MED12). The model is shown to reproduce the main spatial and seasonal biogeochemical characteristics of the Mediterranean Sea. Model estimations of carbon export are also of the same order of magnitude as estimations from in situ observations, and their respective spatial patterns are mutually consistent. Strong differences between the western and eastern basins are evidenced by the model for organic carbon export. Though less oligotrophic than the eastern basin, the western basin only supports $39 \%$ of organic carbon (particulate and dissolved) export. Another major result is that except for the Alboran Sea, the DOC con-
\end{abstract}

tribution to organic carbon export is higher than that of particulate organic carbon (POC) throughout the Mediterranean Sea, especially in the eastern basin. This paper also investigates the seasonality of DOC and POC exports as well as the differences in the processes involved in DOC and POC exports in light of intracellular quotas. Finally, according to the model, strong phosphate limitation of both bacteria and phytoplankton growth is one of the main drivers of DOC accumulation and therefore of export.

\section{Introduction}

The biological pump is recognized as a major component of carbon export in the ocean and plays a significant role in the carbon cycle as a whole (Siegenthaler and Sarmiento, 1993). The sinking of organic particles has long been identified as the main process involved in the biological pump, thereby sustaining the vertical carbon and nutrient gradients in the ocean (Eppley and Peterson, 1979; Sarmiento and Gruber, 2006). Considerable attention has therefore been paid to the export of organic carbon in its particulate form. 
Advances in the characterization of dissolved organic pools have led to a better knowledge of the role of the dissolved organic carbon (DOC) compartment in the ocean carbon cycle. As a non-sinking tracer, the fate of DOC is strongly linked to physical processes and its export occurs via vertical mixing and/or downwelling when it lies in intermediate waters, and via oceanic overturning circulation in deep water (Hansell et al., 2002, 2009). If the early works of Copin-Montégut and Avril (1993) in the Mediterranean Sea and Carlson et al. (1994) in the Sargasso Sea were the first attempts to quantify DOC export flux below the euphotic zone, estimation of detrital particulate organic carbon (POC) export began years before with the deployment of sediment traps and isotopic measurements (Buesseler, 1991).

The seasonal variability in DOC in the euphotic zone has been widely recorded in the subtropical and temperate areas of the ocean (Carlson et al., 1994; Avril, 2002; Hansell and Carlson, 2001; Santinelli et al., 2013). The results of these studies indicate a time lag between DOC production and consumption, causing summer accumulation in the upper layers due to both biotic and abiotic processes, which either alter DOC bioavailability or reduce bacterial activity. The inefficiency of the microbial loop in organic carbon mineralization - the so-called malfunctioning microbial loop (Thingstad et al., 1997) - induces an accumulation of bioavailable DOC. This inefficiency is directly related to low phosphate availability in the upper waters of the Mediterranean Sea (Moutin et al., 2002; Van Wambeke et al., 2002; Thingstad et al., 2005; Santinelli et al., 2013).

In this paper, our aim is to investigate the pathways of organic carbon (OC) at the scale of the Mediterranean Sea, and more specifically to characterize OC export fluxes since this is crucial to determine the efficiency of the biological pump. High resolution 3-D modeling using the biogeochemical mechanistic model Eco3M-MED (Alekseenko et al., 2014) forced by the physical model NEMO-MED12 (Beuvier et al., 2012b) was chosen to address this question. Major modeling work has already been done to estimate organic carbon export using box models (e.g., Toggweiler et al., 2003), ocean carbon-cycle models (e.g., Bopp et al., 2001; Sarmiento et al., 1998; Maier-Reimer et al., 1996; Sarmiento and Gruber, 2006) and ecosystem models coupled with hydrodynamic models (e.g., Le Quéré et al., 2010). Several coupled models have also been developed to study the whole of the Mediterranean Sea, starting with the early simulation by Crispi et al. (1998) and Crise et al. (1998). The number of models designed for this purpose is increasing (Lazzari et al., 2013; Mattia et al., 2013; Macías et al., 2014), but to our knowledge, no modeling work has yet focused on organic carbon fluxes for the entire Mediterranean Sea. Here, our aim is to focus on OC export in the Mediterranean Sea by characterizing and quantifying the associated fluxes, studying their temporal and spatial variability, and providing the first estimations at this scale of the respective contributions of DOC and POC (which refers to the detrital particulate organic carbon only in the present paper) to carbon export. We also aim to analyze the processes involved in DOC and POC production export in light of the intracellular quotas of planktonic organisms calculated by Eco3M-MED. The paper is organized as follows: after this introduction, a succinct overview (Sect. 2) of the hydrodynamical model NEMOMED12 (Sect. 2.1) and the biogeochemical model Eco3MMED (Sect. 2.2) is provided, given that they are described in detail in the aforementioned papers. Simulation setup and data sets used for model comparison are also presented. Section 3 first focuses on the results related to organic carbon inventory and export at the scale of the Mediterranean Basin, and for the purpose of discussion results on intracellular quotas in phytoplankton and bacteria as well as on exudation fluxes are also presented. In Sect. 4, results on export are discussed in the context of previous POC and DOC export evaluations in the Mediterranean Sea, and in light of processes and intracellular quotas in phytoplankton and bacteria. Finally, a supplement is associated with this paper, containing the assessment of the biogeochemical model outputs (nutrients, chlorophyll, primary production and DOC) through comparison with available data and analysis of the main discrepancies.

\section{Material and methods}

\subsection{The hydrodynamic model}

The physical run used in this work is described in Beuvier et al. (2012b). It has been simulated by the regional circulation model NEMO-MED12 Beuvier et al. (2012a), which is part of a suite of Mediterranean regional versions of OPA and NEMO (Madec and the NEMO team, 2008) as OPA-MED16 (Béranger et al., 2005), OPAMED8 (Somot et al., 2006) and NEMO-MED8 (Beuvier et al., 2010).

Model resolution is $1 / 12^{\circ}(\approx 8 \mathrm{~km})$, which means that most of the mesoscale features are explicitly resolved, and the domain includes the whole of the Mediterranean Sea as well as the Atlantic Ocean west of $11^{\circ} \mathrm{W}$ (Fig. 2). More details of the model and its parametrization are given in Beuvier et al. (2012a).

The simulation was initiated in October 1958 with temperature and salinity data representative of the 1955-1965 period using the MEDATLAS data set (MEDAR/MEDATLAS Group, 2002; Rixen et al., 2005). Atmosphere forcings are applied daily and come from the ARPERA data set (Herrmann and Somot, 2008), a 55-year simulation at $50 \mathrm{~km}$ and daily resolutions. SST-relaxation and water-flux correction terms, as well as fresh water input from rivers and the Black Sea and Atlantic exchanges, are the same as described in Beuvier et al. (2010, 2012a). 


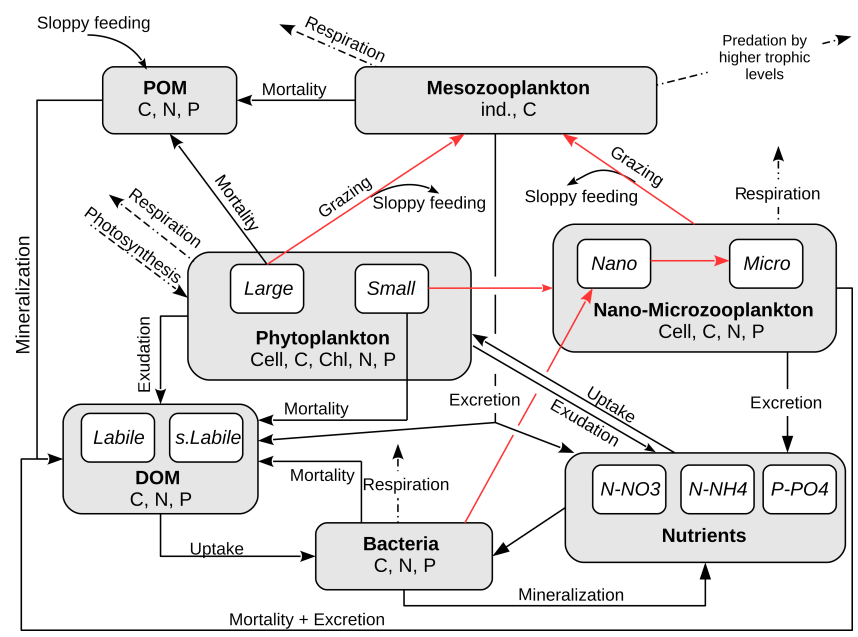

Figure 1. Conceptual diagram of the biogeochemical model Eco3M-MED. Grey boxes represent major compartments and white boxes sub-compartments. State variables for each sub-compartment are listed at the bottom of compartment boxes. Red arrows indicate grazing processes from the prey to the predator.

\subsection{The biogeochemical model}

The biogeochemical model Eco3M-MED is embedded in the Eco3M modular numerical tool (Baklouti et al., 2006b), and its structure is similar to the model presented in Alekseenko et al. (2014). Figure 1 summarizes the interactions between the state variables through the biogeochemical processes. We chose to represent three different element cycles $\mathrm{C}, \mathrm{N}$ and $\mathrm{P}$ in order to reproduce the different limitations and co-limitations observed in the Mediterranean Sea. Silicon, potentially limiting in some regions (Leblanc et al., 2003), is not represented in the model, as P and N limitations are the most common ones in the Mediterranean Sea. Six different planktonic functional types (PFTs; see Le Quéré et al., 2005, for a proper definition) are represented: two primary producers (phytoplankton), one decomposer (heterotrophic bacteria) and three consumers (nano-, micro- and meso-zooplankton). The structure of the trophic web thereby includes the main PFTs of the Mediterranean Sea (SiokouFrangou et al., 2010).

Each PFT of the model is represented through several state variables, namely $\mathrm{C}, \mathrm{N}$ and $\mathrm{P}$ (and $\mathrm{Chl}$ for producers) concentrations and a cell number (i.e., an abundance), except for meso-zooplankton, which is only represented through its $\mathrm{C}$ concentration and its abundance (in individuals per unit volume). Intracellular ratios (i.e., the ratio between two elemental concentrations) as well as intracellular quotas (i.e., the quantity of a given element per cell) can therefore be calculated dynamically by the model. Intracellular ratios are indicators of plankton stoichiometry, i.e., of its $\mathrm{C}: \mathrm{N}: \mathrm{P}$ elemental composition. Early biogeochemical models (NPZD models) have considered a constant $\mathrm{C}: \mathrm{N}: \mathrm{P}$ ratio in plankton given by the canonical Redfield ratio of $106: 16: 1$ (Redfield, 1958). Based on Droop's work (e.g., Droop, 1968, 1975), an increasing number of biogeochemical models (e.g., Baretta et al., 1995; Geider et al., 1998) have in recent decades assumed flexible plankton stoichiometry. Though Droop's original quota function relating growth rate to the intracellular quota of the limiting element was based on cell quotas, these biogeochemical models have used intracellular ratios instead of quotas to regulate the rate of biomass synthesis (and other process rates) with quota functions similar to that of Droop. These flexible stoichiometry models have been widely used in the framework of theoretical batch or chemostat studies (e.g., Geider et al., 1998; Baklouti et al., 2006b) or for large-scale studies with ERSEM (Baretta et al., 1995), BFM (Vichi et al., 2007) or other (e.g., Moore et al., 2002) models. In such models, substrate uptake and biomass synthesis are decoupled, but cell division is not explicitly represented.

Intracellular quotas (or cell quotas) as they are defined in the present paper are indicators of the $\mathrm{C}, \mathrm{N}$ and $\mathrm{P}$ cellular content of plankton. They are an original feature of the Eco3M-MED model in the category of 3-D coupled physical-biogeochemical models. This model is based on the assumption that there is a minimum $\left(Q_{X}^{\min }\right)$ and a maximum $\left(Q_{X}^{\max }\right)$ intracellular content for each element $X$ (among $\mathrm{C}$, $\mathrm{N}, \mathrm{P}) . Q_{X}^{\min }$ can be interpreted as the amount of element $X$ used in cellular structure and machinery and the accumulated surplus as storage for future growth (Klausmeier et al., 2008). The variability in cell quotas has indeed been widely evidenced through several experimental and in situ studies (e.g., Brown and Harris, 1978; Fukuda et al., 1998; Lovdal et al., 2008; Heldal et al., 2003; Bertilsson et al., 2003; Wilhelm et al., 2013).

The use of cell numbers as state variables and of the associated intracellular quotas offers several advantages: firstly, it makes it possible to distinguish between cell division, which is described by a specific equation (see Eq. 1), biomass synthesis, and uptake. Second, intracellular quotas are indicative of the actual internal status of cells, i.e., they indicate whether cells are rich or depleted in a given element, while intracellular ratios only provide relative values. In other words, a given value of intracellular ratio $Q_{X Y}$ can correspond to several different cell statuses (for example, a given $\mathrm{C}: \mathrm{N}$ ratio can be obtained with an infinity of pairs of $\mathrm{C}$ and $\mathrm{N}$ intracellular concentration values). Thus, intracellular ratios can only provide information on the internal relative quantity of $X$ as compared to that of $Y$, while intracellular quotas inform on intracellular absolute quantities. The latter information is very useful for the analysis of plankton dynamics since it is informative about the nutritional status of each PFT of the trophic web (see the Discussion section). It is also a good proxy of the quality of the prey available for zooplankton (i.e., whether prey are rich or depleted in a given element). Thirdly, the parameters determined at cell level can be used 


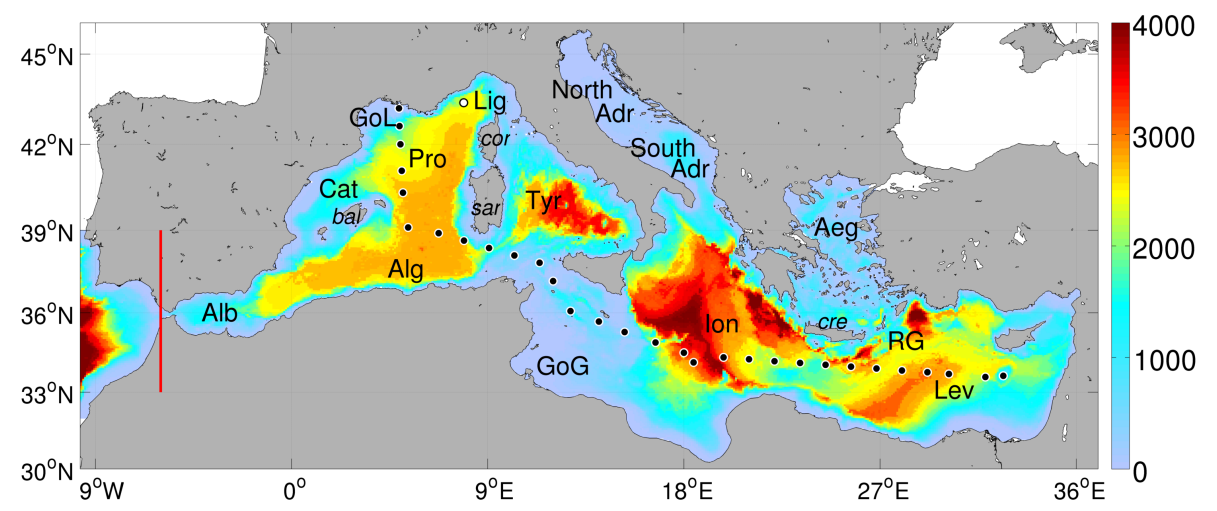

Figure 2. Bathymetry of the grid in meters; black dots represent the BOUM cruise stations (Moutin et al., 2012), while the white dot represents the DyFaMed position (Marty and Chiavérini, 2010). The area west of the red line constitutes the buffer zone. Abbreviations indicate different sub-basin names and islands (in italic). Terminology is taken from Millot and Taupier-Letage (2005). From west to east, Alb stands for Alboran Sea, Cat for Catalan Sea, GoL for Gulf of Lion, Pro for Provencal sub-basin, Alg for Algerian Basin, Lig for Ligurian Sea, Tyr for Tyrrhenian Sea, GoG for Gulf of Gabes, North Adr and South Adr for north and south Adriatic Sea, respectively, Ion for Ionian sub-basin, Aeg for Aegean Sea, Lev for Levantine sub-basin, and RG for Rhodes Gyre. Major island names are also plotted: bal stands for the Balearic Islands, sar for Sardinia, cor for Corsica and cre for Crete.

without using conversion factors. For example, the uptake rate measured at cell level (Talarmin et al., 2011), or grazing parameters expressed in number of prey per predator per unit time, such as the ones provided in Christaki et al. (2009) for heterotrophic nanoflagellates (HNF) and ciliates, can be used directly.

Intracellular quotas have already been used in previous modeling studies to study phytoplankton growth (Klausmeier et al., 2004) or the dynamics of the planktonic food web (Thingstad et al., 2005). In the latter study, however, cell quotas of carbon were assumed to be fixed in the protozoa, while fixed $\mathrm{C}: \mathrm{N}$ ratios were assumed for bacteria and phytoplankton. Moreover, this model was used without being coupled with a physical model (i.e., for the simulation of microcosm and Lagrangian experiments).

In the model, the producers are split into two different PFTs according to their theoretical size, i.e., large phytoplankton $(>10 \mu \mathrm{m})$, mainly encompassing diatoms, and small phytoplankton $(<10 \mu \mathrm{m})$, which includes picophytoplankton and the remaining nanophytoplankton. The two PFTs have different parameters, distinct predators and fuel different detritic pools (Fig. 1). Decomposers are represented by heterotrophic bacteria and are responsible for the organic matter mineralization, including hydrolysis of particles. Zooplankton is divided into three different size groups: heterotrophic nanoflagellate (HNF), which feeds on bacteria and small phytoplankton; ciliate, which feeds on small phytoplankton and HNF; and mesozooplankton (copepods), which feeds on ciliate, HNF and large phytoplankton. Copepods are the only metazoans in the model, and mechanisms such as individual growth, egg production or reproduction are implicitly represented (Alekseenko et al., 2014).
The processes used in the model are extensively described in the aforementioned reference. However, for the purposes of the present paper, we recall that POC is fueled by the natural mortality of largest organisms (mesozooplankton, diatoms and ciliates) and by the egestion of fecal pellets and sloppy feeding by mesozooplankton, and consumed by POC hydrolysis to DOC. The DOC pool has many inputs (phytoplankton exudation, zooplankton excretion, mortality of small organisms, POC hydrolysis) and a single output (uptake by bacteria). The formulations of most of the biogeochemical processes, for which details are extensively given in Baklouti et al. (2006a, 2011), Mauriac et al. (2011), and Alekseenko et al. (2014), follow cell-level mechanistic considerations. Intracellular ratios $\left(Q_{X Y}\right)$ and intracellular quo$\operatorname{tas}\left(Q_{X}\right)$ are used to regulate growth via Droop's quota function (Droop, 1968) and net uptake and grazing rates via Geider's limitation formulation (Geider et al., 1998). For example, the specific growth rate (i.e., the division rate) $\mu$ of all unicellulars in the model is given by the following equation:

$\mu=\mu^{\max } \min _{X \in\{\mathrm{C}, \mathrm{N}, \mathrm{P}\}}\left(1-\frac{Q_{X}^{\min }}{Q_{X}}\right)$,

where $\mu^{\max }$ is the maximum division rate and $Q_{X}^{\min }$ the minimum intracellular $X$ quota.

Grazing, primary production and uptake rates are controlled firstly by the organism's environment (either prey or nutrient concentration, or light availability). Secondly, the internal cell status represented by intracellular quotas and ratios drives a feedback regulation of the net incorporated biomass through quota functions. Hence, the uptaken surplus (which becomes more and more significant as the intracellular quota approaches $Q^{\max }$ ) is either released in its initial form or exuded in the form of DOM. In the same way, excre- 
tion and fecal pellet production fluxes are proportional to the grazing flux and to a quota function the value of which increases as the quota approaches $Q^{\max }$. Furthermore, in order to represent sloppy feeding, $10 \%$ of the material grazed by mesozooplankton directly fuels the particulate organic matter stock. Respiration rates are estimated via energy costs for every plankton activity (Alekseenko et al., 2014). Nitrification is represented through first-order kinetics, while the particulate hydrolysis function depends on bacteria intracellular quotas (POC hydrolysis increases with bacterial C limitation). Grazing by higher trophic levels is implicitly taken into account via quadratic mortality affecting only mesozooplankton. The grazing function is a Holling type II response (Holling, 1959; Kooijman, 2000) for multiple prey. The only difference with the configuration of Alekseenko et al. (2014) lies in the formulation used to represent predator preferences for multiple prey. We here used the "kill the winner" (KTW) formulation depicted in Vallina et al. (2014), which combines active switching (i.e., the preference of a predator for a given prey depends on prey density) and an ingestion rate always increasing with the total biomass of prey. This active-switching formulation was used to preserve food web diversity (e.g Prowe et al., 2012) and to prevent unrealistic predator-prey oscillations.

Since the model relies on a mechanistic basis, parameters are mainly physiological (and measurable) and they were either taken from literature or derived from other parameters on the basis of physiological considerations and in the interests of greater consistency between parameters. For example, maximum intracellular quotas are inferred from minimum ones as done in Thingstad et al. (2005). Another example lies in the relationship between the maximum uptake rate of a given element, which is the product of the maximum specific growth rate and the maximum intracellular quota in that element. Other examples as well as the whole set of parameters are given in Alekseenko et al. (2014).

\subsection{Model coupling}

The models NEMO and Eco3M-MED have been coupled for the first time. The coupling between the hydrodynamic and biogeochemical models is offline, i.e., biological retroaction on the physics is not taken into account. Daily-averaged water velocities were used for the advection of biogeochemical tracers, using a MUSCL scheme (horizontal and vertical diffusion fluxes are calculated according to a centered scheme). The time step used for the numerical integration of the tracer conservation equations equals $1200 \mathrm{~s}$. A sinking velocity of $2 \mathrm{~m} \mathrm{~d}^{-1}$ is applied only on the particulate organic pool (i.e., the detrital compartment). The aim of this compartment is to represent particles with different sizes and sinking velocities and the value of $2 \mathrm{~m} \mathrm{~d}^{-1}$ is within the usual range found in the literature (Vichi et al., 2007; Fasham et al., 2006). The light attenuation formulation in the water column is based on Morel (1988) results.

\subsection{Initial and boundary biogeochemical conditions}

Initial nutrient and chlorophyll fields are derived from annual means of Mediterranean Sea climatological data (Schaap and Lowry, 2010). The remaining biogeochemical variables are derived from chlorophyll using conversion factors derived from published works (see Alekseenko et al., 2014, for details).

A "buffer zone" has been defined between the domain western boundary and the Strait of Gibraltar (from 11 to $6^{\circ} \mathrm{W}$ ), in which a damping procedure towards Atlantic conditions has been applied. The restoring time is 2 days west of $7.5^{\circ} \mathrm{W}$, linearly increasing to 90 days from 7.5 to $6^{\circ} \mathrm{W}$ (Fig. 2). Atlantic nutrient concentrations come from the World Ocean Atlas monthly climatology (Garcia et al., 2006), so that the nutrients damping in the "buffer zone" takes into account the nutrients' monthly variability. Since in the database some values of the $\mathrm{NO} 3: \mathrm{PO} 4$ ratio were very high (likely due to inaccuracies in phosphate measurements), we decided to compute phosphate profiles from that of nitrate by imposing a Redfield ratio of 16 in order to be more consistent with observed $\mathrm{NO}_{3}: \mathrm{PO}_{4}$ ratios in this region (Gómez, 2003). Chlorophyll concentrations were not provided in this database. We therefore used in situ data from the SeaDataNet database to create a mean vertical chlorophyll profile for the Atlantic, and then used a climatology of surface chlorophyll from the GlobColour product in this region to represent an annual cycle of the chlorophyll vertical profile. The remaining Atlantic biogeochemical variables were derived from chlorophyll using the same procedure as for initial conditions.

Nutrient $\left(\mathrm{NO}_{3}\right.$ and $\left.\mathrm{PO}_{4}\right)$ inputs from riverine influx and coastal runoffs are derived from (Ludwig et al., 2009), following the same procedure as for the riverine freshwater inputs in the circulation model (Beuvier et al., 2010, 2012b). The nutrient influx of the 29 rivers included in the RivDis database (Vörösmarty et al., 1996) are taken into account in the simulation, while the nutrients of the remaining rivers from the (Ludwig et al., 2009) database are averaged for every sub-basin and distributed along their respective subbasin's coast as coastal runoffs. Dissolved organic carbon inputs in the Mediterranean Sea are distributed in every subbasin according to the riverine DOC estimates of (Ludwig, 1996) (a total of $\sim 1.8 \mathrm{Tg} \mathrm{Cyr}^{-1}$ in the whole of the Mediterranean Sea). Sub-basin DOC inputs were then distributed among fluvial estuarine and coastal runoffs to match circulation model freshwater geographical distribution (Palmiéri, 2014; Palmiéri et al., 2015).

Mass exchanges with the Black Sea in the Dardanelles Strait are treated as river inputs, with nutrients and DOC input concentrations provided by the SESAME project (Tugrul and Besiktepe, 2007; Meador et al., 2010). But, since the $\mathrm{NO}_{3}$ budget indicates a negative net flux of $\mathrm{NO}_{3}$ the Dardanelles Strait (i.e., exiting from the Mediterranean), $\mathrm{NO}_{3}$ flux at the Dardanelles is set to zero and the outcome is trans- 
ferred on the Aegean sub-basin's runoffs. These runoffs are artificially reduced in order to keep the riverine budget of $\mathrm{NO}_{3}$ in the Aegean sub-basin realistic.

\subsection{Simulation setup}

Using the biogeochemical initial conditions defined in Sect. 2.4, we have conducted a 5-year simulation using physical forcings from the years 1973 to 1977 . This first simulation was considered a "spin-up" in order to reduce the impact of state variables adjustment in the simulations. It has deliberately been done long enough before the Eastern Mediterranean Transient period (starting around 1991), which is not stable enough to be chosen as a spin-up period. Moreover, due to high computational costs, it was not possible to run this first simulation until the year 1996. We therefore used the final biogeochemical state of this spin-up as initial conditions for a second simulation running from 1996 to 2012. In this second simulation, only the years following 1998 are considered, since the first 3 years were treated as an additional spin-up beyond which the stability of the run was ensured (i.e., no drift could be observed).

\subsection{Data description}

The aim of the present work is to study and quantify organic carbon export fluxes using a 3-D physical-biogeochemical model. For this purpose, our first aim was to assess the reliability of our model by examining the agreement between different model outputs and corresponding available data: chlorophyll, nutrients, DOC concentrations and primary production rates.

The model outputs were assessed at different time and space scales through comparisons with (i) satellite-derived chlorophyll at basin scale, (ii) BOUM cruise transect of nutrients and DOC vertical profiles measured during the stratified period, and (iii) the time series data collected at DyFaMed station.

\subsubsection{Chlorophyll data derived from satellite}

Among the specificities of the Mediterranean Sea, its strong oligotrophy and the major influence of colored dissolved organic matter make the use of classical satellite chlorophyll products difficult (e.g., Claustre et al., 2002). Several algorithms have already been developed (Bosc et al., 2004; D'Ortenzio et al., 2002; Volpe et al., 2007) using different satellite reflectances and data sets. Here, we used a daily surface chlorophyll product delivered by the MyOcean project (http://www.myocean.eu). In this product, chlorophyll concentrations have been derived using the MEDOC4 algorithm developed by Volpe et al. (2007). This algorithm was built using a large data set of chlorophyll concentrations collected in situ and reflectance measurements from three satellites (SeaWIFS, MERIS and MODIS), constituting a homogeneous series from September 1997 to March 2012.

\subsubsection{The BOUM cruise data}

The BOUM cruise took place during summer 2008 (from 16 June to 20 July) and traversed both the western and eastern basins of the Mediterranean Sea (Moutin et al., 2012). The data acquired during this cruise provide a unique picture of the biogeochemical status of the Mediterranean Sea since many biogeochemical variables were observed. Measurements of nutrients and DOC concentrations were used to perform a basin-scale comparison during the summer stratified period with the model outputs obtained at the same dates as the cruise and averaged over this period.

\subsubsection{The DyFaMed station data}

The DyFaMed station is located in the Ligurian Sea at $7.9^{\circ} \mathrm{E}$ and $43.4^{\circ} \mathrm{N}$ (Fig. 2) and is isolated from coastal inputs by the Mediterranean Northern Current. A strong winter mixing is observed in this area, although it is less intense than the deep convection occurring in the Provencal sub-basin (Marshall and Schott, 1999). Nutrients (Pasqueron de Fommervault et al., 2015), chlorophyll (Marty et al., 2008), dissolved organic carbon (Avril, 2002) and primary production rate (Marty et al., 2008) time series were used for comparison. The comparison of the model outputs with DyFaMed time series can be done through different methods. The simplest consists in using a single grid point which is the nearest to the DyFaMed station location. This implies that the model perfectly reproduces spatial patterns in this region, which is obviously never the case. On the other hand, the use of model outputs averaged on several grid points around the DyFaMed station amounts to dampening signal variability. We finally chose to use the nearest grid point to the DyFaMed station, while assessing spatial variability in the eight neighboring grid points (see Supplement).

\section{Results}

\subsection{Organic carbon inventory and export}

\subsubsection{Dissolved organic carbon inventory}

In the following section, mDOC refers to the modeled dissolved organic carbon integrated over the first $100 \mathrm{~m}$ of the water column. Seasonal variations in $\mathrm{mDOC}$ are given in Fig. 3. Low mDOC values $\left(<1 \mathrm{~mol} \mathrm{~m}^{-2}\right)$ are observed throughout the year in the Alboran Sea (and up to the Balearic Islands), the northern Levantine Basin, and in some well-marked structures in the Tyrrhenian Sea. In contrast, very high $\mathrm{mDOC}$ values (up to $5 \mathrm{~mol} \mathrm{~m}^{-2}$ ) can be found throughout in the north Adriatic Sea and along the Libyan coast. Apart from these regions, $\mathrm{mDOC}$ is low everywhere (below $2 \mathrm{~mol} \mathrm{~m}^{-2}$ ) in winter (Fig. 3a), and this is also true in spring except in the region of the spring bloom in the Provencal sub-basin. In the western basin, highest DOC concentra- 

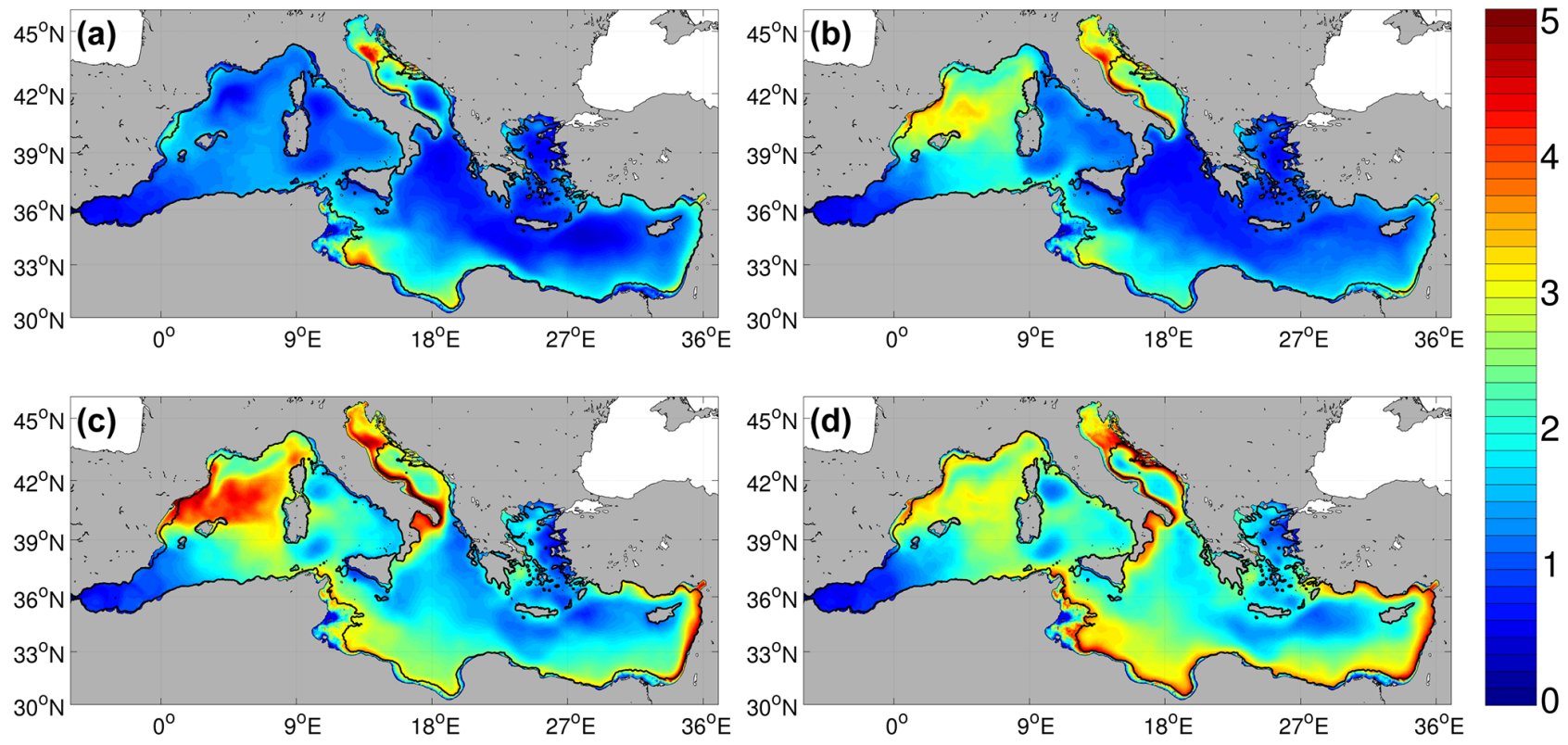

Figure 3. Modeled dissolved organic carbon inventory $\left(\mathrm{mol} \mathrm{m}^{-2}\right)$ integrated over the first $100 \mathrm{~m}$. Maps are averaged over the 2000-2012 period in (a) winter (December-February), (b) spring (March-May), (c) summer (June-August), and (d) autumn (September-November).

tions are generally observed in summer, with values reaching $4 \mathrm{~mol} \mathrm{~m}^{-2}$ in the bloom region of the Liguro-Provençal subbasin. In the eastern basin, they are reached in autumn and mostly concern the Adriatic Sea and the regions along the southern and eastern coasts.

\subsubsection{Particulate organic carbon inventory}

In what follows, mPOC refers to the modeled particulate organic carbon integrated over the first $100 \mathrm{~m}$ of the water column. Seasonal variations in $\mathrm{mPOC}$ are given in Fig. 4. Unlike $\mathrm{mDOC}, \mathrm{mPOC}$ highest values are observed in winter and spring. This is mostly true for the western basin since, in the eastern basin, $\mathrm{mPOC}$ remains low $\left(<0.05 \mathrm{~mol} \mathrm{~m}^{-2}\right)$ all over the year, except for the Adriatic Sea and a local maximum in the Rhodes Gyre distinguishable in spring. During winter (Fig. 4a), the highest values of mPOC $\left(>0.5 \mathrm{~mol} \mathrm{~m}^{-2}\right)$ are found in the region of the Alboran Sea and the surrounding Balearic Islands and also in the Liguro-Provençal subbasin, though with much lower concentrations. In the Adriatic Sea, $\mathrm{mPOC}$ is in the range $[0.1 ; 0.2] \mathrm{mol} \mathrm{m}^{-2}$. Elsewhere, $\mathrm{mPOC}$ is low $\left(<0.2 \mathrm{~mol} \mathrm{~m}^{-2}\right)$. During spring (Fig. $\left.4 \mathrm{~b}\right)$, the maximum $\mathrm{mPOC}$ is observed in the region of the bloom in the Provencal sub-basin $\left(\approx 0.4 \mathrm{~mol} \mathrm{~m}^{-2}\right)$ and the north Adriatic Sea. During summer and autumn (Fig. $4 \mathrm{c}$ and d), overall values are low $\left(<0.05 \mathrm{~mol} \mathrm{~m}^{-2}\right)$, except in the Alboran Sea (where values reach $0.3 \mathrm{~mol} \mathrm{~m}^{-2}$ ) and in the north Adriatic Sea.

\subsubsection{Dissolved and particulate organic carbon export}

Organic carbon fluxes are computed by adding the contribution of advection (vertical velocity and settling velocity for POC) and vertical diffusion (implicitly representing turbulent and convective mixing) fluxes across a horizontal section of the grid. Negative fluxes account for downward fluxes. For clarity, modeled fluxes will be referred to as $F_{\mathrm{DOC}}, F_{\mathrm{POC}}$ and $F_{\mathrm{OC}}$ as the sum of the latter two. $F_{\mathrm{DOC}}$ and $F_{\mathrm{POC}}$ have been computed at 100 and $200 \mathrm{~m}$ so as to include most of the productive layer and to allow the comparison in space and time between regions. These depths are also used in several other modeling studies (Lévy et al., 1998; Bopp et al., 2001).

The yearly amount of mOC export at $100 \mathrm{~m}$ is equal to $48.4 \mathrm{MtC} \mathrm{yr}^{-1}$. The eastern basin is the main contributor to this export with a total export of 28.7 against 19.7 $\mathrm{MtC} \mathrm{yr}^{-1}$ for the western basin. mDOC export is equal to $38.8 \mathrm{MtC} \mathrm{yr}^{-1}$, and comparatively, river inputs of $\mathrm{mDOC}$ are equal to $1.8 \mathrm{MtC} \mathrm{yr}^{-1}$, thereby representing less than $5 \%$ of the exported mDOC. mDOC contribution to the total organic carbon flux is dominant. In the western basin, the total amounts of exported $\mathrm{mPOC}$ and $\mathrm{mDOC}$ below $100 \mathrm{~m}$ are respectively 7.0 and $12.7 \mathrm{MtC} \mathrm{yr}^{-1}$, meaning that $64 \%$ of this export is due to DOC. In the eastern basin, DOC is responsible for $90 \%$ of the organic carbon export below $100 \mathrm{~m}$, with an annual flux of $26.1 \mathrm{MtC} \mathrm{yr}^{-1}$ (compared to $2.6 \mathrm{MtC} \mathrm{yr}^{-1}$ for POC). 

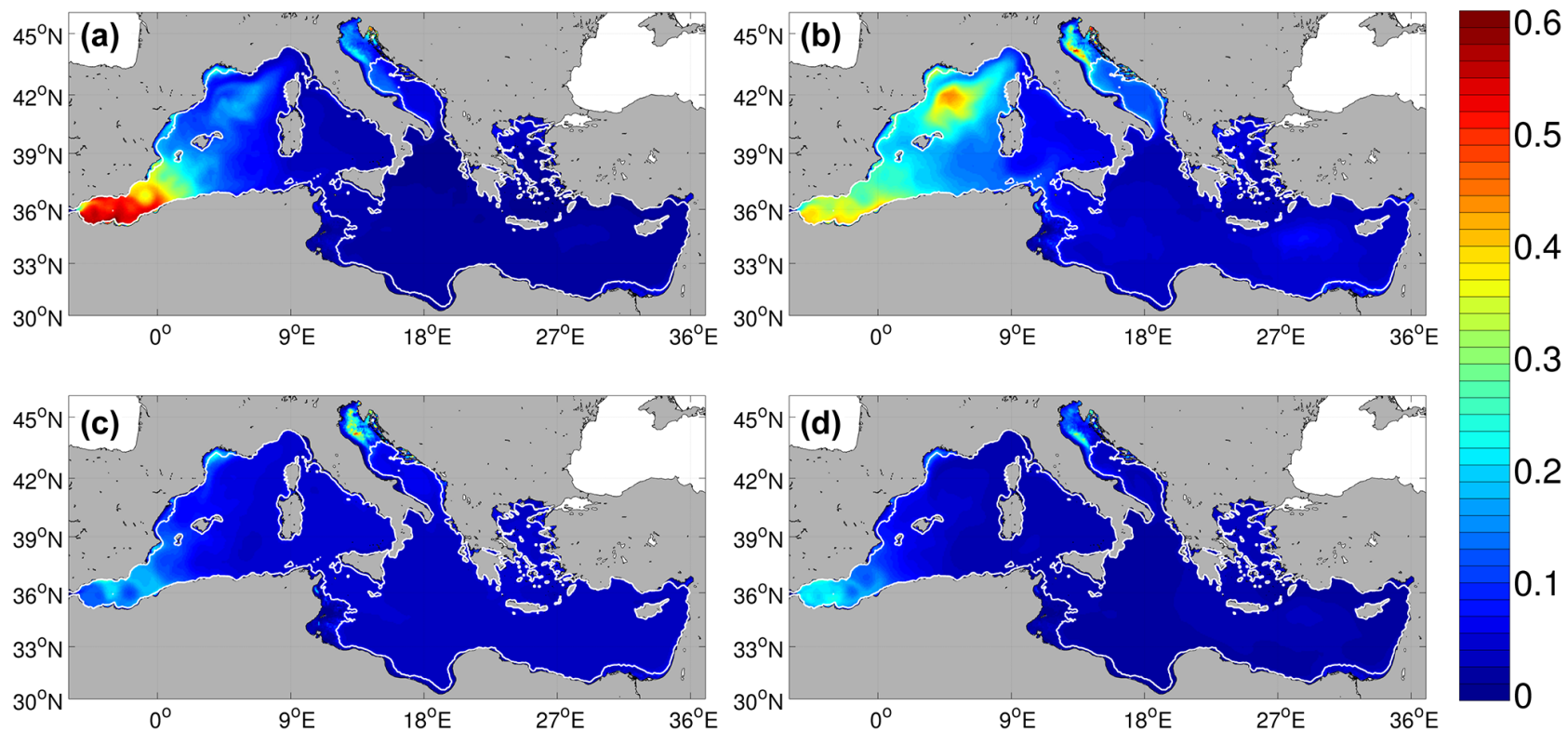

Figure 4. Modeled particulate organic carbon inventory $\left(\mathrm{mol} \mathrm{m}^{-2}\right)$ integrated over the first $100 \mathrm{~m}$. Maps are averaged over the 2000-2012 period in (a) winter (December-February), (b) spring (March-May), (c) summer (June-August), and (d) autumn (September-November). White lines are the 0 and $100 \mathrm{~m}$ isolines.
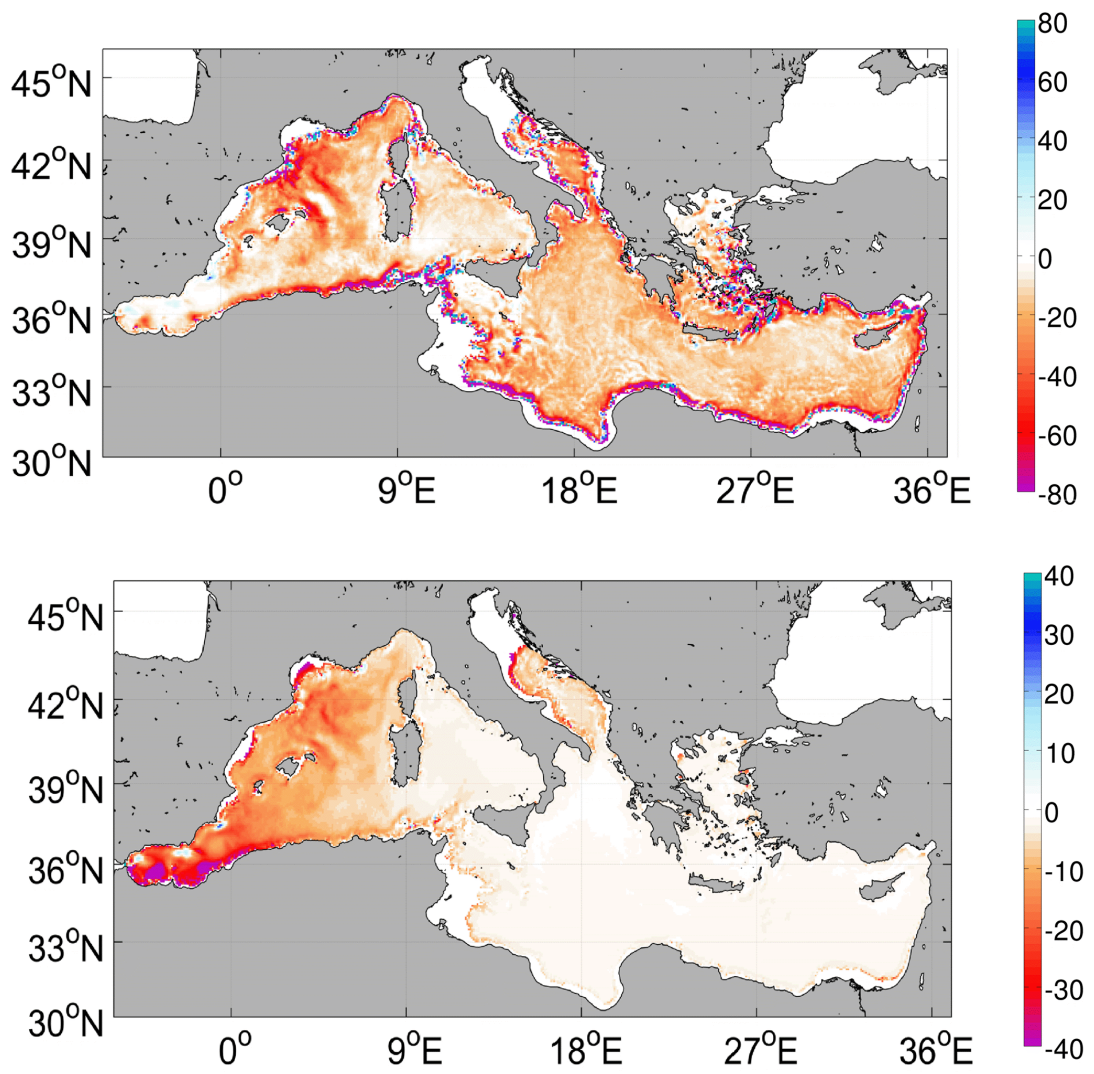

Figure 5. Maps of modeled annual DOC fluxes (top) and POC fluxes (bottom) below the $100 \mathrm{~m}$ layer in $\mathrm{gC} \mathrm{m}^{-2} \mathrm{yr}^{-1}$. Note the color scale differences. Negative (red) means a downward flux. 


\subsubsection{Spatial variability in export fluxes}

Mean $F_{\mathrm{OC}}$ over the whole basin equals $-22.8 \mathrm{gC} \mathrm{m}^{-2} \mathrm{yr}^{-1}$, but a wide spatial variability can be observed in Fig. 5. Hence, the main regions of mOC export are the LiguroProvençal sub-basin, the Alboran Sea, the southern continental slopes and the Adriatic Sea.

In the western basin, high positive values (i.e., upward) of $F_{\mathrm{DOC}}$ are simulated along the French and Spanish coasts, the entrance to the Strait of Sicily and northeastern Corsica. Excluding these areas, the highest downward fluxes of DOC are calculated in the Provencal sub-basin (especially in the region of deep convection), the north of the Balearic Islands and along the Algerian slope, where downward $F_{\mathrm{DOC}}$ can be higher than $60 \mathrm{gC} \mathrm{m}^{-2} \mathrm{yr}^{-1}$.

In the eastern basin, the complexity of topography and hydrodynamic regimes in the Aegean Sea may explain the high heterogeneity of the fluxes calculated in this region that are difficult to interpret. Highest downward $F_{\text {DOC }}$ values are located along the continental slope from the Libyan to the Turkish coasts and in the Adriatic Sea. Elsewhere (i.e., in the open sea), $F_{\text {DOC }}$ distribution is more homogeneous, with a median of $-17 \mathrm{gC} \mathrm{m}^{-2} \mathrm{yr}^{-1}$.

A strong difference exists between the western and eastern basins regarding $F_{\mathrm{POC}}$ at $100 \mathrm{~m}$. The mean value of downward $F_{\mathrm{POC}}$ throughout the western basin is -9.8 compared to $-2.4 \mathrm{gC} \mathrm{m}^{-2} \mathrm{yr}^{-1}$ in the eastern basin (Fig. 5 bottom).

In the western basin, $F_{\mathrm{POC}}$ is the highest in the Alboran Sea, particularly in the southeast of the easily identifiable anticyclonic eddies. Following the pathway of the Atlantic waters, downward $F_{\mathrm{POC}}$ values decrease, reaching absolute values lower than $5 \mathrm{gC} \mathrm{m}^{-2} \mathrm{yr}^{-1}$ in the Tyrrhenian Sea. In the Provençal Basin, high POC fluxes linked to the deep convection, with values ranging from -15 to $-30 \mathrm{gC} \mathrm{m}^{-2} \mathrm{yr}^{-1}$, have been modeled. Throughout the eastern basin, $F_{\mathrm{POC}}$ is low except in the Adriatic Sea.

Finally, as suggested in Fig. 5, the spatial correlation between POC and DOC fluxes is weak almost everywhere. Regions of high POC or DOC export generally do not match. The only areas associated with both high POC and DOC exports are the Algerian coast, the Adriatic coast, the regions of deep convection and a band east of the Balearic Islands.

\subsubsection{Seasonal variability}

The seasonal variability and the spatial distribution of $F_{\mathrm{DOC}}$ and $F_{\mathrm{POC}}$ differ significantly (Figs. 6 and 7). In winter (Fig. 6a), $F_{\mathrm{DOC}}$ values are high in almost all of the Mediterranean Basin except the Alboran Sea, with maximum values that can be observed in the Provencal sub-basin and along the continental slopes, especially along the southern and eastern coasts of the eastern basin. $F_{\mathrm{DOC}}$ distribution is quite similar in autumn, though with values that are significantly lower everywhere. During the rest of the year, $F_{\mathrm{DOC}}$ values are very low in spring nearly everywhere, and almost zero in summer.
In several areas (Tyrrhenian and Adriatic seas, Levantine and Ionian basins), high downward $F_{\mathrm{DOC}}$ values are observed in winter, while they are almost zero during the rest of the year.

High downward POC fluxes at $100 \mathrm{~m}$ were calculated from winter to spring west of $7^{\circ} \mathrm{E}$, namely in the Alboran Sea and the Provencal sub-basin (Fig. 7). In these regions, maximum values are reached in late winter (February-March) in the Alboran Sea, and in spring (March-April) in the Algerian Sea and the Provencal sub-basin. POC export in the eastern basin (excluding the Adriatic Sea) is very weak (even in the Rhodes Gyre) all year long. Maximum values can, however, be identified in spring in the Tyrrhenian Sea, the Levantine basins (except for the Rhodes Gyre, where the maximum is earlier in winter) and in the Adriatic Sea.

\subsubsection{Export below $200 \mathrm{~m}$}

Below $100 \mathrm{~m}$, organic carbon is progressively consumed via the bacterial activity and respiration. At $200 \mathrm{~m}$, the calculated mean export fluxes of total organic carbon are reduced by almost 87 and $64 \%$, respectively, compared to those at $100 \mathrm{~m}$ in the western and eastern basins. However, the ratio between export at these two depths is highly variable, depending on the region (see Fig. 8).

For POC (Fig. 8a), if we consider first the regions where the annual $F_{\mathrm{POC}}$ values are significant, i.e., west of $7^{\circ} \mathrm{E}$ (see Fig. 5 bottom), the 200 to $100 \mathrm{~m}$ ratio is lower than 0.25 (i.e., only $25 \%$ of the carbon exported at $100 \mathrm{~m}$ goes below $200 \mathrm{~m}$ ) in a region including the Alboran Sea, the western Algerian Sea and the Balearic Sea. This ratio is slightly higher but still below 0.3 for the central Algerian Sea and the Adriatic Sea. The Provencal sub-basin is the only region of high export below $200 \mathrm{~m}$ with a ratio about 0.4 . In regions of low annual POC export (i.e., east of $7^{\circ} \mathrm{E}$ ), the ratio ranges between 0.4 and 0.8 in the Tyrrhenian Sea and the Ionian and Levantine basins.

For DOC (Fig. 8b), the ratio is more spatially variable, and in some regions the ratio is higher than 0.4 , namely in the Provencal sub-basin, along the coasts of the Levantine Basin, in the northern Ionian Basin, the Rhodes Gyre and the Adriatic Sea. Some patches of high ratios are also visible close to the Algerian coast. Elsewhere the ratio ranges from almost zero (Tyrrhenian Sea, the Alboran Sea) to 0.2 in the eastern basin.

\subsection{Intracellular quotas in bacteria and phytoplankton}

Intracellular quotas in phytoplankton and bacteria are required for a further analysis of POC and DOC export fluxes and are presented in the following section. The carbon quota $\left(Q_{\mathrm{C}}\right)$ in small phytoplankton is maximum (corresponding to a relative quota $>0.7$; see Fig. 9) in spring and summer in almost all of the Mediterranean Sea, though $Q_{\mathrm{C}}$ values are slightly lower in spring than in summer in the western basin, especially in the bloom region (Fig. 9). In autumn, though 

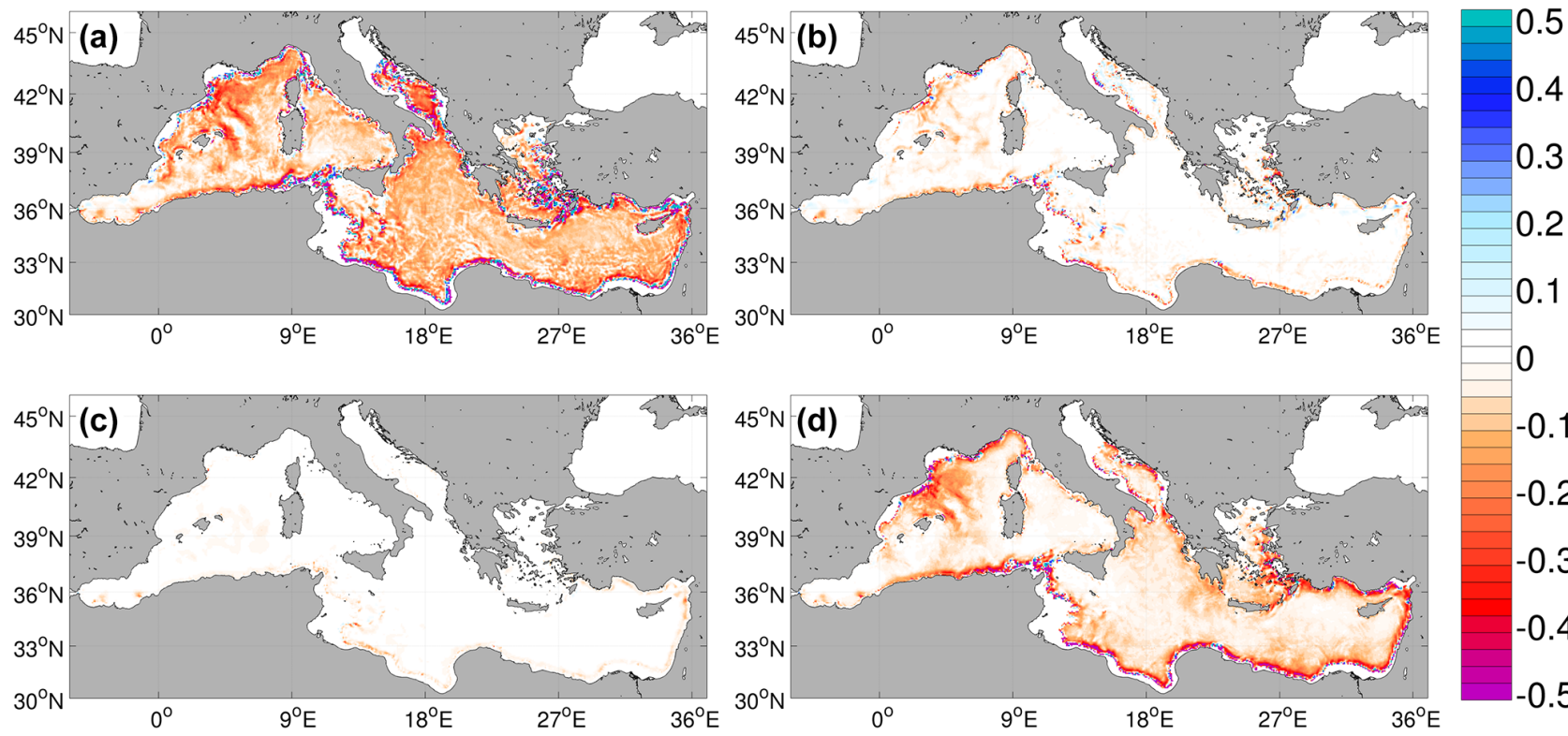

Figure 6. Maps of modeled DOC fluxes across the $100 \mathrm{~m}$ layer $\left(F_{\mathrm{DOC}}\right)$ in $\mathrm{gC} \mathrm{m}^{-2} \mathrm{~d}^{-1}$ in (a) winter (December-February), (b) spring (March-May), (c) summer (June-August), and (d) autumn (September-November). Negative (red) means a downward flux.
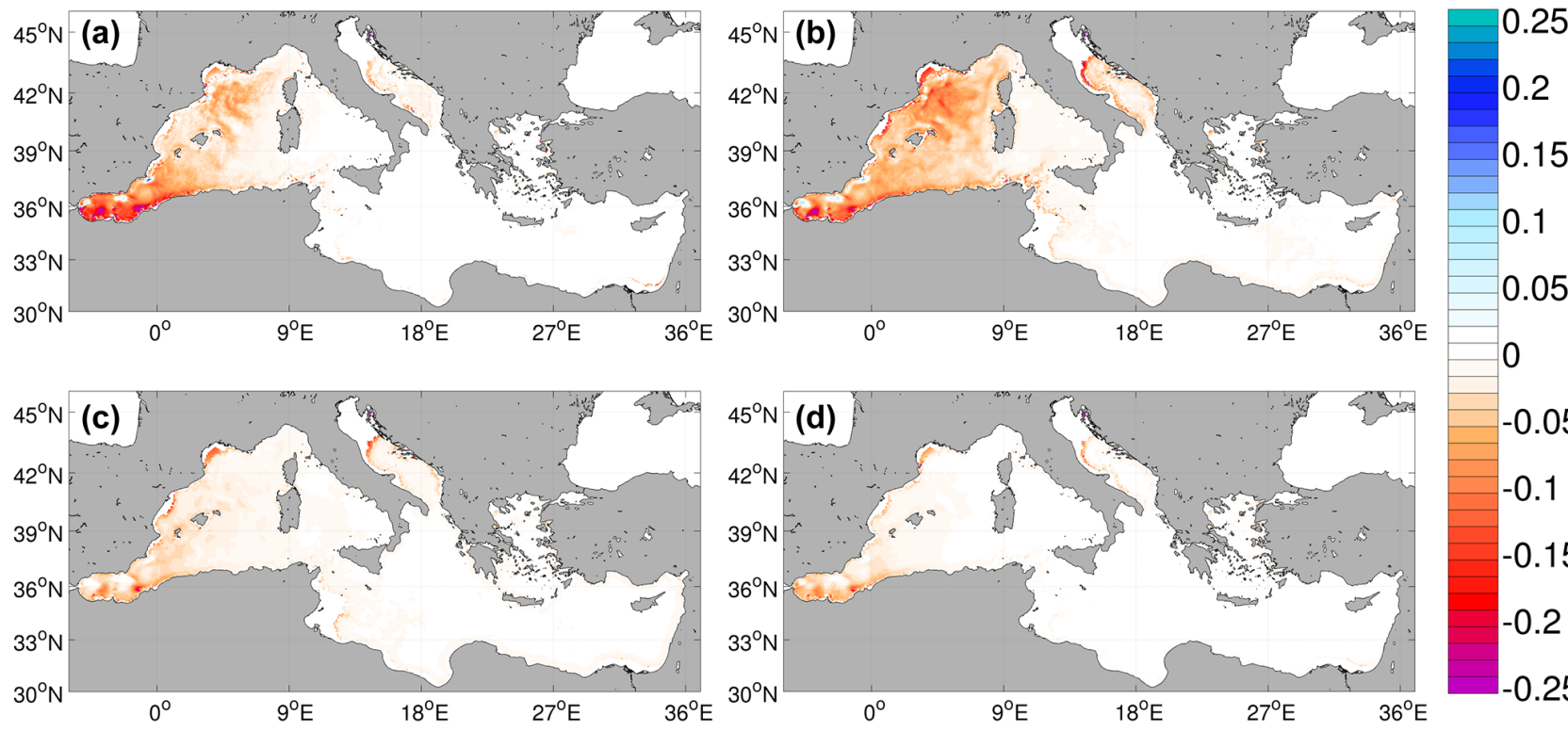

Figure 7. Maps of modeled POC fluxes across the $100 \mathrm{~m}$ layer $F_{\mathrm{POC}}$ in $\mathrm{gC} \mathrm{m}^{-2} \mathrm{~d}^{-1}$ in (a) winter (December-February), (b) spring (MarchMay), (c) summer (June-August), and (d) autumn (September-November). Negative (red) means a downward flux.

$Q_{\mathrm{C}}$ has decreased in nearly all of the Mediterranean Sea, $Q_{\mathrm{C}}$ values along the southern and eastern coasts of the eastern basin are significantly higher than in the rest of the open sea. In winter, $Q_{\mathrm{C}}$ values are even lower, with the local maximum located in the Balearic Sea and in the south of the eastern basin.

The seasonal signal of the $\mathrm{P}$ quota $\left(Q_{\mathrm{P}}\right)$ in small phytoplankton is nearly the opposite of that of $Q_{\mathrm{C}}$, with the high- est $Q_{\mathrm{P}}$ values in autumn and mostly in winter in nearly the whole of the Mediterranean Basin, and the lowest ones in spring and summer (Fig. 10). All year long, $Q_{\mathrm{P}}$ values are lower along the southern and eastern coasts than in the rest of the eastern basin.

Bacteria $Q_{\mathrm{C}}$ generally increases from winter to summer in most of the Mediterranean Basin (Fig. 11). In autumn, the decrease in $Q_{\mathrm{C}}$ is observed everywhere except throughout 


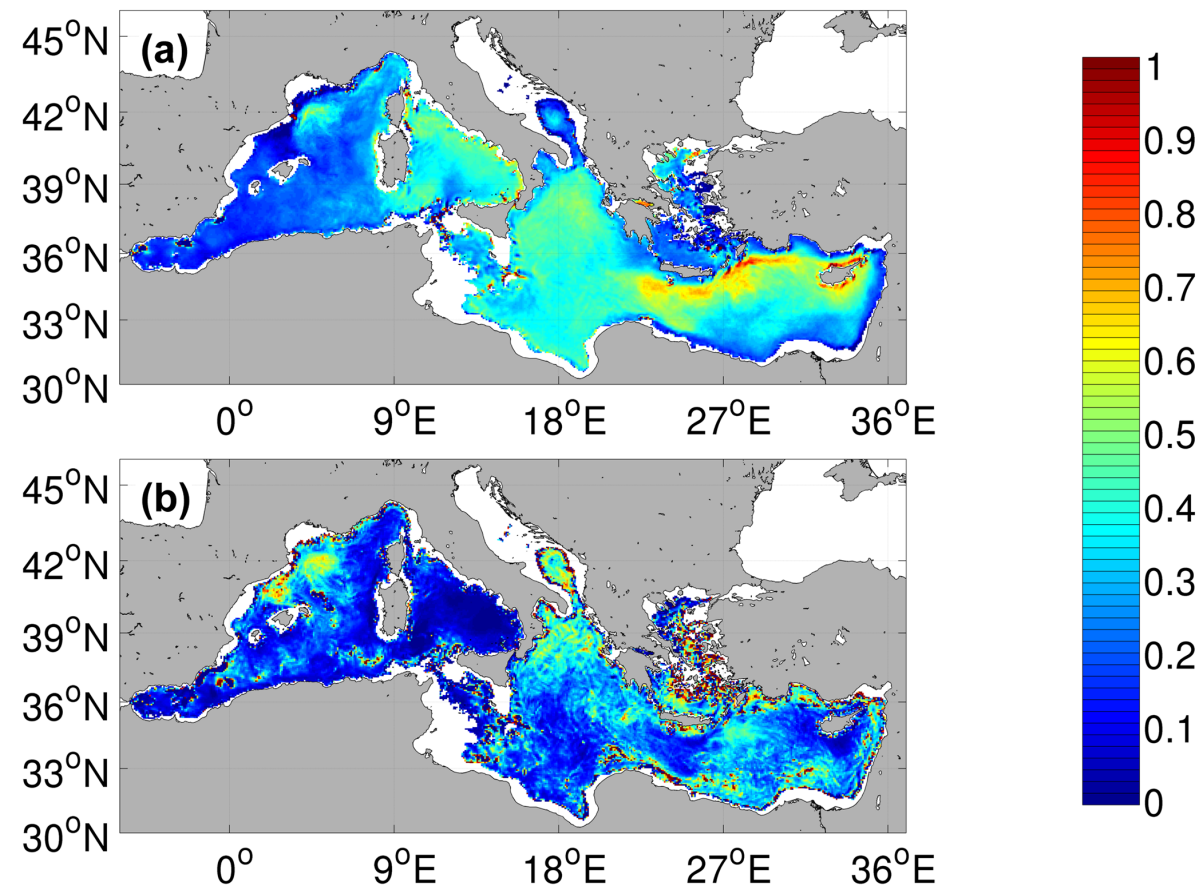

Figure 8. Ratio between export fluxes at 200 and at $100 \mathrm{~m}$ for (a) POC and (b) DOC.
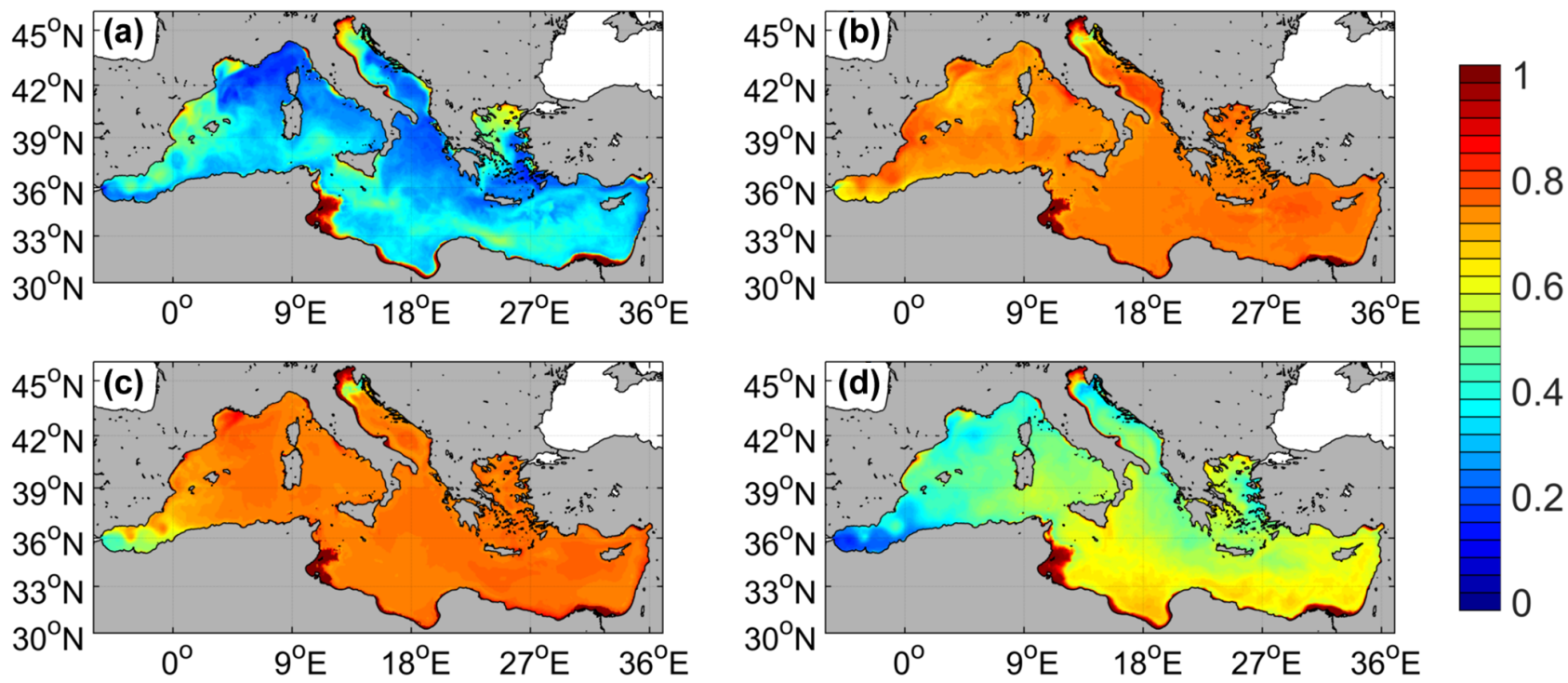

Figure 9. Seasonal variations in mean 0-50 m carbon relative quotas in small phytoplankton: (a) winter (December-February), (b) spring (March-May), (c) summer (June-August), and (d) autumn (September-November). Relative quotas are equal to 0 when the quota is minimum (i.e., when $Q_{\mathrm{C}}=Q_{\mathrm{C}}^{\min }$ ) and equal to 1 when the quota is maximum (i.e., when $Q_{\mathrm{C}}=Q_{\mathrm{C}}^{\max }$ ).

the same already identified region (namely along the southern and eastern coasts of the eastern basin). All year round, $Q_{\mathrm{C}}$ values are higher in this region than in the rest of the basin and even reach the $Q_{\mathrm{C}}^{\max }$ value in summer and autumn thus indicating that carbon needs for bacteria growth are fully satisfied. In the deep convection regions (Liguro-Provençal sub-basin, Adriatic, Rhodes Gyre region), and in some ed- dies well identified in the Alboran and Tyrrhenian seas, the carbon quota is generally lower than in the surrounding waters, especially in autumn.

Bacteria $Q_{\mathrm{P}}$ values are very low everywhere in spring and summer except in the latter regions. The minimum $Q_{\mathrm{P}}$ values (i.e., the highest bacterial P limitation) are observed in spring in the western basin, while they are reached in summer in the 

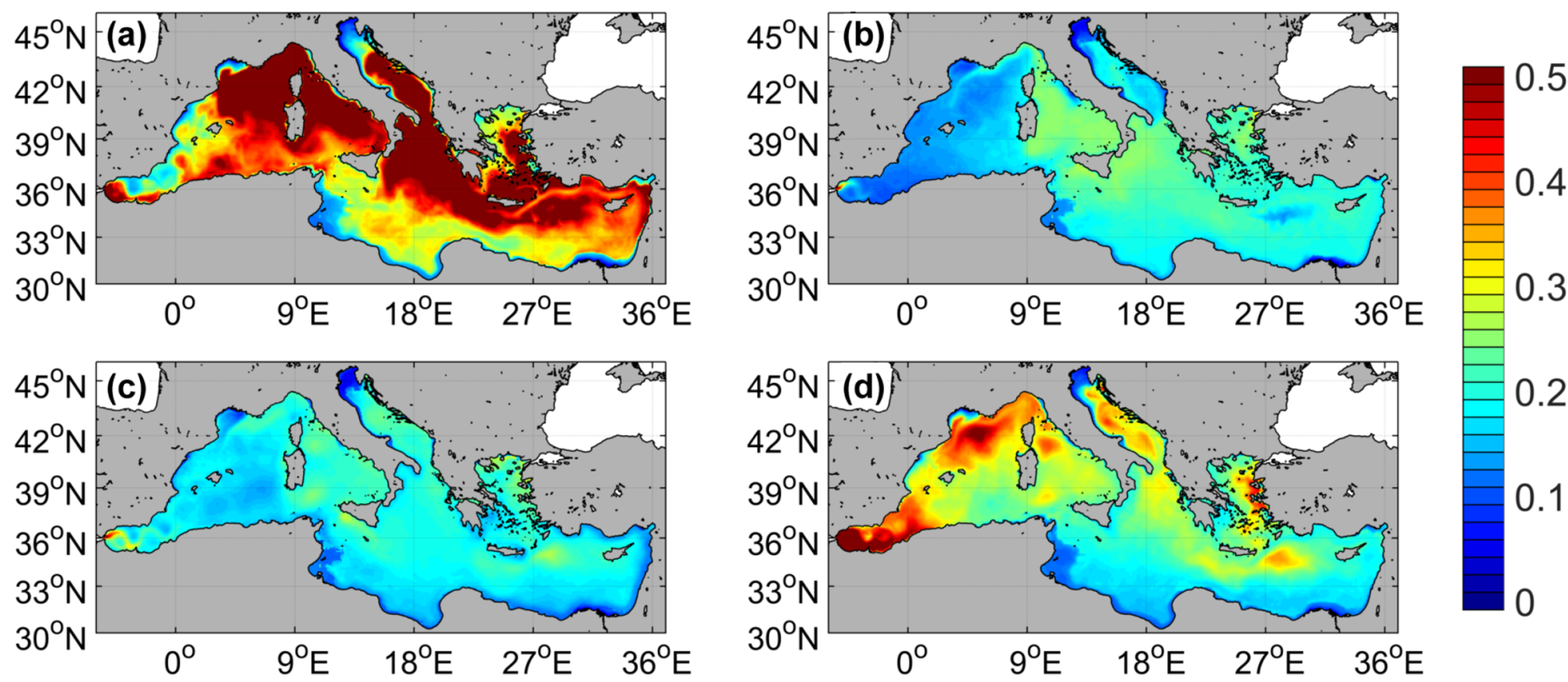

Figure 10. Seasonal variations in mean $0-50 \mathrm{~m}$ phosphorus relative quotas in small phytoplankton: (a) winter (December-February), (b) spring (March-May), (c) summer (June-August), and (d) autumn (September-November). Relative quotas are equal to 0 when the quota is minimum (i.e., when $Q_{\mathrm{P}}=Q_{\mathrm{P}}^{\min }$ ) and equal to 1 when the quota is maximum (i.e., when $Q_{\mathrm{P}}=Q_{\mathrm{P}}^{\max }$ ).
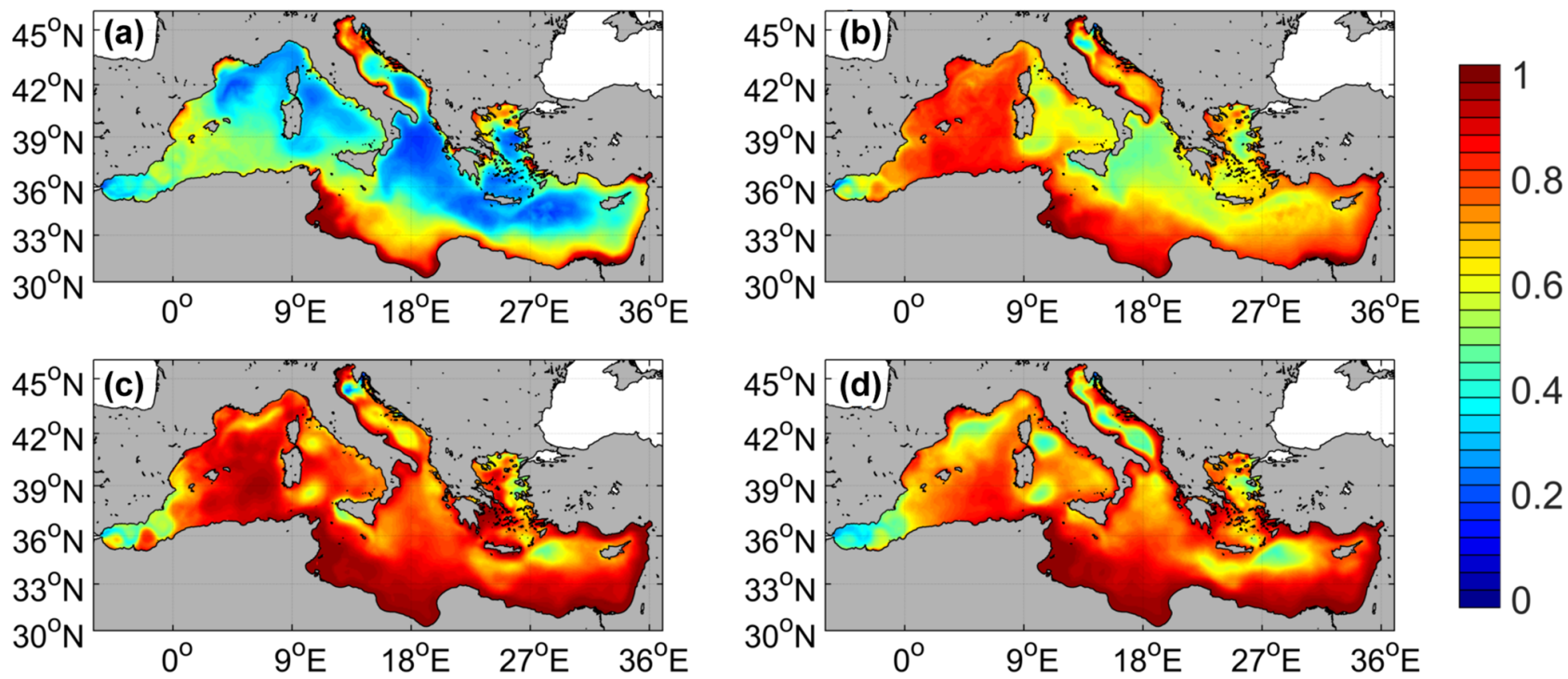

Figure 11. Seasonal variations in mean 0-50 m carbon relative quotas in bacteria: (a) winter (December-February), (b) spring (March-May), (c) summer (June-August), and (d) autumn (September-November). Relative quotas are equal to 0 when the quota is minimum (i.e., when $Q_{\mathrm{C}}=Q_{\mathrm{C}}^{\min }$ ) and equal to 1 when the quota is maximum (i.e., when $Q_{\mathrm{C}}=Q_{\mathrm{C}}^{\max }$ ).

eastern basin. As for phytoplankton, $Q_{\mathrm{P}}$ values are lower all year round along the southern and eastern coasts than in the rest of the eastern basin.

\subsection{DOC exudation by phytoplankton}

DOC exudation by large phytoplankton mainly occurs in the bloom region of the western basin (especially in the deep convection zone) in (late) winter and spring, when accumu- lated fluxes are up to $2.8 \mathrm{molC} \mathrm{m}^{-2}$ (Fig. 13). Elsewhere, exudation fluxes are very low throughout the year, except in the Alboran Sea, two eddies of the Adriatic Sea and in the Rhodes Gyre region.

The seasonality and the spatial patterns of DOC exudation flux by small phytoplankton are rather different. The highest mDOC exudation fluxes are modeled in spring in the western basin, especially in the Gulf of Lion and the deep convection zone, where accumulated fluxes up to $3 \mathrm{molC}^{-2}$ are cal- 

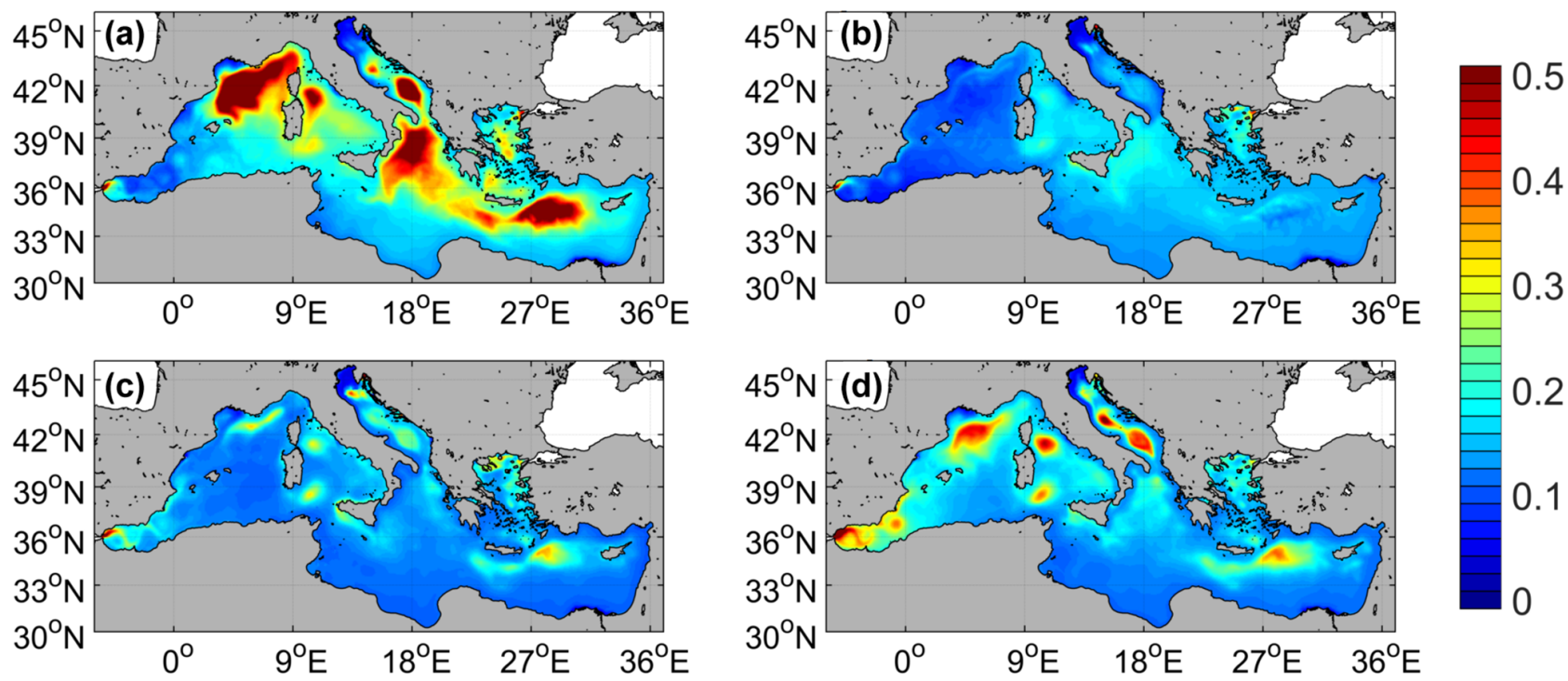

Figure 12. Seasonal variations in mean 0-50 m phosphorus relative quotas in bacteria: (a) winter (December-February), (b) spring (MarchMay), (c) summer (June-August), and (d) autumn (September-November). Relative quotas are equal to 0 when the quota is minimum (i.e., when $Q_{\mathrm{P}}=Q_{\mathrm{P}}^{\min }$ ) and equal to 1 when the quota is maximum (i.e., when $Q_{\mathrm{P}}=Q_{\mathrm{P}}^{\max }$ ).
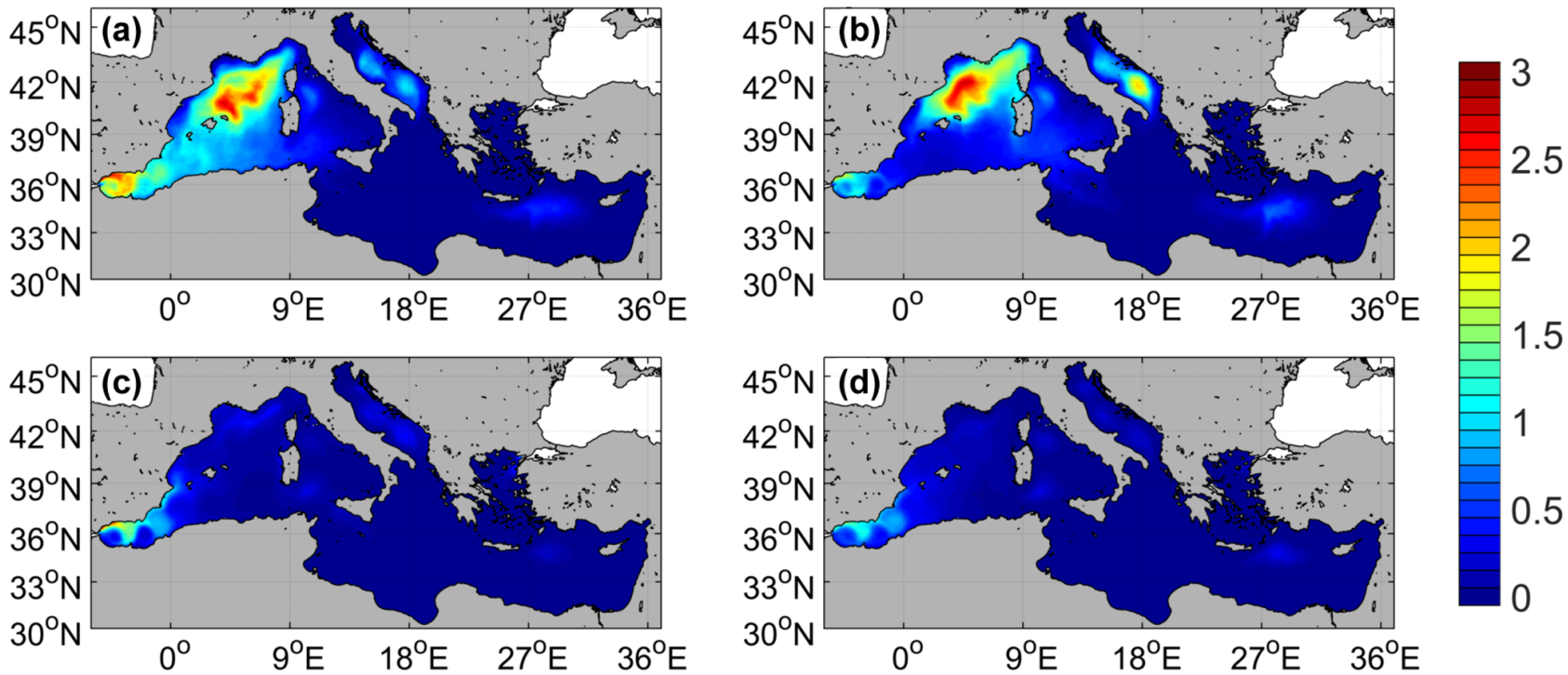

Figure 13. Seasonal variations in DOC mean 0-100 m exudation accumulated flux by large phytoplankton (in $\mathrm{molC}^{-2}$ ).

culated. In the eastern basin, the highest fluxes are observed in spring and summer. During these seasons, apart from the Adriatic Sea (especially in the north and along the eastern coast, where accumulated fluxes also reach $3 \mathrm{molC} \mathrm{m}^{-2}$ ) and some hot spots (Rhodes Gyre, Nile plume), mDOC exudation seems homogeneous, though a north-south gradient is present. Hot spots of mDOC exudation are also present nearly all year long in the plumes of the main rivers.

\section{Discussion}

4.1 The dissolved fraction in the organic carbon export is predominant at the scale of the Mediterranean Sea

One of the main results of this study is that $\mathrm{mDOC}$ export exceeds $\mathrm{mPOC}$ export in the whole of the Mediterranean Basin, with the exception of the Alboran Sea (west of $3^{\circ} \mathrm{W}$ ). This is consistent with the comparisons between POC and DOC exports performed in the Tyrrhenian, northern Ionian and Lig- 

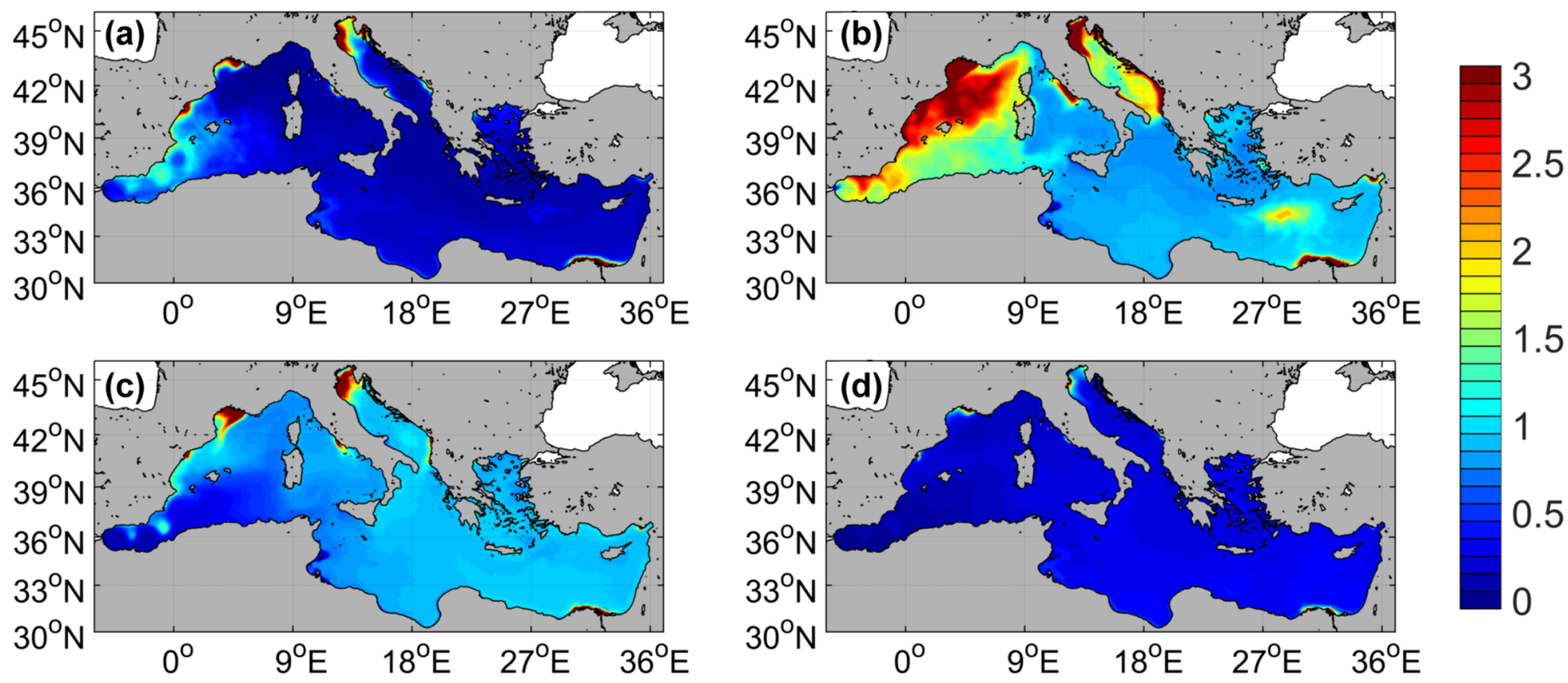

Figure 14. Seasonal variations in mDOC mean 0-100 m exudation accumulated flux by small phytoplankton (in $\mathrm{molC}^{-2}$ ).

urian seas by Copin-Montégut and Avril (1993), Santinelli et al. (2013) or by Lefèvre et al. (1996), who estimated that DOC was the main source of remineralization processes in the aphotic layer. In the western basin, the ratio of $\mathrm{mDOC}$ over mPOC export fluxes ranges between 2 and 5 , and is approximately equal to 4 at the DyFaMed grid point. Observations at the DyFaMed station led to a oDOC export estimation of about $11.9 \mathrm{gC} \mathrm{m}^{-2} \mathrm{yr}^{-1}$, markedly higher than oPOC export estimations at $200 \mathrm{~m}$ (Avril, 2002, and references therein). Moreover, oPOC fluxes calculated by Miquel et al. (2011) during the 2001-2005 period ranged from 1.6 to $2.6 \mathrm{gC} \mathrm{m}^{-2} \mathrm{yr}^{-1}$. For comparison, $\mathrm{mPOC}$ export flux was in the range [1.5;3.1] $\mathrm{gC} \mathrm{m}^{-2} \mathrm{yr}^{-1}$ during the same period. In the northwestern basin, the modeled ratio is about 2 at 100 and $200 \mathrm{~m}$, while in the same area a modeling study (Herrmann et al., 2014) led to a ratio at $200 \mathrm{~m}$ which ranged from 0.9 to 1.8 , even though the corresponding export fluxes were higher than in the present study.

The ratio between modeled DOC and POC exports at $100 \mathrm{~m}$ ranges from 2 to 8 in the Adriatic Sea. In the same region, a oDOC flux of $15.4 \mathrm{gC} \mathrm{m}^{-2} \mathrm{yr}^{-1}$ (compared to $23 \mathrm{gC} \mathrm{m}^{-2} \mathrm{yr}^{-1}$ for $\mathrm{mDOC}$ ) was estimated from observations by Santinelli et al. (2013). This is nearly 5 times higher than the measured oPOC export flux estimated by Boldrin et al. (2002) under the euphotic zone of $3.3 \mathrm{gC} \mathrm{m}^{-2} \mathrm{yr}^{-1}$ (compared to $4.5 \mathrm{gC} \mathrm{m}^{-2} \mathrm{yr}^{-1}$ for mPOC export at $100 \mathrm{~m}$ ). These oDOC and oPOC fluxes were however estimated at different periods.

In the eastern basin, mDOC export is regularly more than 10 times that of mPOC, due to the very weak mPOC export and to the high mDOC export along the coasts and in the open sea. Few observations and estimations are available for this region. In the northern Ionian Sea, Boldrin et al. (2002) reported annual oPOC fluxes at $150 \mathrm{~m}$ of $2.4 \mathrm{gC} \mathrm{m}^{-2} \mathrm{yr}^{-1}$, which are on the same order of magnitude as the annual mPOC fluxes calculated in the same area but for a different period $\left(1.2\right.$ and $0.6 \mathrm{gC} \mathrm{m}^{-2} \mathrm{yr}^{-1}$ at 100 and $200 \mathrm{~m}$, respectively).

DOC predominance in the OC export flux is first due to the higher DOC gross production fluxes as compared to those of POC, and this still holds if the POC to DOC hydrolysis flux is ruled out (i.e., if the DOC inputs due to POC hydrolysis are not taken into account). At the scale of the Mediterranean Basin as a whole, $\mathrm{mDOC}$ and $\mathrm{mPOC}$ gross production fluxes are indeed respectively equal to $20 \times 10^{12}$ and $2.7 \times 10^{12} \mathrm{molC} \mathrm{yr}^{-1}$. In the western basin, mDOC predominance in the export of OC still holds, though to a lesser extent, with $\mathrm{mDOC}$ and $\mathrm{mPOC}$ gross production fluxes respectively equal to $8.7 \times 10^{12}$ and $1.9 \times 10^{12} \mathrm{molC} \mathrm{yr}^{-1}$. In the following section, the reasons for these differences will be further analyzed in light of the processes associated with DOC and POC production.

\subsection{POC and DOC exports are characterized by different processes and timing}

Strong disparities can be identified between the spatial patterns of the annual DOC and POC export fluxes (Fig. 5), with rather homogeneous DOC export fluxes across the Mediterranean Sea (though with well-identified regions of maximum export that will be analyzed later), contrasting with the high east-west gradient in POC export. This is consistent with in situ measurements of daily POC export across the Mediterranean Sea at $200 \mathrm{~m}$ that showed much lower POC export in the eastern basin than in the western basin (Moutin and Raimbault, 2002). 
There are also considerable differences in the seasonality of DOC and POC export fluxes (Figs. 6 and 7). Over the whole of the Mediterranean Sea, $88 \%$ of DOC export occurs between November and February, which is consistent with observations at the DyFaMed station, where $90 \%$ of annual DOC export was linked to winter mixing (Avril, 2002). By contrast, POC export is more even throughout the year, and during the same period only $23 \%$ of POC is exported.

In the model, only the detrital compartment (POC) is allowed to sink. The sinking process is therefore the only source of explicit distinction between POC and DOC exports, but it is probably not sufficient to explain the strong aforementioned differences. The main source of difference lies in the biogeochemical processes that fuel or consume POC and DOC pools (see Sect. 2.2). In the model, POC is fueled by the natural mortality of the largest organisms (mesozooplankton, diatoms and ciliates) and by the egestion of fecal pellets and sloppy feeding by mesozooplankton. Thus, higher concentrations of large organisms in the western basin, primarily due to the spring bloom in the Liguro-Provençal sub-basin associated with high primary production rates is the main reason for the higher POC production and export in this basin. Hence, POC export is at a maximum in spring (i.e., from March to May; see Fig. 7), since it is the period including the maximum and mostly the end of the bloom, that is, the period during which detrital concentrations of large organisms are the highest. Moreover, according to the model, mortality is the main process that fuels the POC pool, far ahead of the egestion and sloppy feeding processes. More generally, a strong correlation between annual primary production and POC export has been evidenced at basin scale (Spearman's rank correlation coefficient is 0.84 ), while this is not the case for DOC export (correlation below 0.01).

As shown in the Results section, the regions of high POC or DOC export are generally not the same, except for the regions characterized by high primary production rates during the spring bloom, namely the Alboran Sea, the bloom region in the NW Mediterranean Sea and the south of the Adriatic Sea (see also Sect. 4.3). Apart from these regions, the annual DOC export at $100 \mathrm{~m}$ is relatively high in almost all of the Mediterranean Basin, particularly in autumn and winter, and is the consequence of DOC accumulation in the $0-100 \mathrm{~m}$ layer during summer and autumn (Fig. 3). DOC export does indeed take place when DOC-rich surface waters plunge or are mixed with poorer deeper waters.

This accumulation of DOC is primarily due to water stratification that results in nutrient depletion in the $0-100 \mathrm{~m}$ layer. As a result, the pool of DOC in phytoplankton is saturated with newly synthesized organic compounds since photosynthesis (i.e., carbon production), which is not controlled by $\mathrm{P}$ availability, takes place more rapidly than is required to supply the needs of growth (cell division being limited by the intracellular quota of P). This results in high DOC exudation by phytoplankton, which is the main source of DOC in the model. The contribution of zooplankton excretion is at a maximum in spring in the bloom region of the NW Mediterranean but always remains much lower than that of exudation (results not shown). Similarly, the annual contribution of POC hydrolysis to the DOC production flux is weak (around $10 \%$ ). Bacteria are the first consumers of DOC, and the second ingredient for DOC accumulation is therefore a strong nutrient limitation that will highly restrict the bacteria growth rate (see Eq. 1). In this situation, DOC availability may exceed bacteria needs and result in DOC accumulation when DOC production by phytoplankton exceeds DOC uptake by bacteria. This process is enhanced in hydrodynamic situations where the surface layers are isolated from the deep waters (i.e., stratification period). Such a mechanism of DOC accumulation due to a malfunctioning microbial loop has already been described in Thingstad et al. (1997) and is also the main driver of DOC accumulation in the model. Destratification in autumn leads to a net export as well as an increase in DOC consumption through bacterial activity, driven by nutrient supply from deep water.

\subsection{DOC accumulation in light of intracellular quotas}

The regions of highest DOC export fluxes correspond to the regions where the highest DOC accumulation occurs. It is therefore informative to analyze the occurrence of DOC accumulation in light of intracellular quotas. Geographical and hydrological considerations are indeed not sufficient for a full understanding of the DOC accumulation pattern at the scale of the Mediterranean Sea.

It has already been said that, according to the model, phytoplankton exudation is the primary source of DOC. High DOC exudation by phytoplankton occurs in nutrient-depleted waters. In such a situation $\mathrm{N}$ and/or P phytoplankton nutrient quotas are low and limit growth rate (i.e., the cell division rate). In the model, the phytoplankton (and bacteria) cell division rate is indeed controlled by the most strongly limiting element among $\mathrm{C}, \mathrm{N}$ and $\mathrm{P}$ (see Eq. 1). In other words, the intracellular quota which is the closest to its minimum value controls the division rate. When $\mathrm{P}(\mathrm{and} / \mathrm{or} \mathrm{N})$ is the most strongly limiting, growth will proceed at a low rate and the carbon input due to photosynthesis will rapidly meet phytoplankton needs, thus resulting in an increase in the carbon quota $Q_{\mathrm{C}}$. Since DOC exudation flux per cell increases with $Q_{\text {C }}$ through a Geider et al. (1998) non-linear quota function, DOC exudation flux will highly increase as the quota approaches its maximum value $Q_{\mathrm{C}}^{\max }$. Phytoplankton carbon quota is therefore a good indicator of DOC exudation.

In the oligotrophic Mediterranean Sea, nutrient (and mostly $\mathrm{P}$ in the model) depletion is at a maximum at the end or just after the spring bloom, or under well-established conditions of water stratification, thus leading to maximum exudation fluxes (see Figs. 13 and 14). In the rest of the Mediterranean, DOC exudation is at a maximum in (late) spring and summer, and mainly due to small phytoplankton. The latter is 
indeed characterized by low phosphorus quotas (see Fig. 10) and high carbon quotas (see Fig. 10).

The driving processes of DOC accumulation are not the same in the western and the eastern Mediterranean. In the western Mediterranean, and especially in the enlarged bloom region, large phytoplankton blooms first and is rapidly $\mathrm{P}$ limited (as early as February) and the same occurs for small phytoplankton although later (i.e., only in spring; see Fig. 10). This is consistent with observations performed in the NW Mediterranean Sea (Gulf of Lion) (Diaz et al., 2001). In this situation, the high phytoplankton exudation fluxes are not only due to phytoplankton carbon quotas that are relatively high (around 50-60\%; see the small phytoplankton carbon quota in Fig. 9), resulting in relatively high exudation flux per cell, but also to the high phytoplankton abundance. Though exudation fluxes are high in (late) winter due to large phytoplankton (Fig. 13a), the high bacteria P quotas (Fig. 12a) combined with winter mixing prevent DOC accumulation (Fig. 3a). In spring, and mostly in late spring, bacteria are strongly P-limited (Fig. 12b) since the bloom has rapidly consumed the available nutrients and vertical mixing has stopped. As a result, DOC accumulation starts in this region (Fig. 3b) and reaches its maximum in summer (Fig. 3c) during the stratification period since DOC exudation by phytoplankton still proceeds (though at a lower rate) and bacteria are still strongly P-limited (Fig. 12c). Finally, the end of the stratification in autumn will not only dilute the DOC-rich surface concentrations with DOC-poor deep waters but also allow the $\mathrm{P}$ enrichment of surface waters (see the increase in bacteria $Q_{\mathrm{P}}$ in Fig. 12d).

In the eastern Mediterranean, DOC accumulation is mainly visible along the southern and eastern coasts. Moreover, it starts later than in the western Mediterranean (i.e., in summer against spring for the west), and is at a maximum in autumn. In the model, the Atlantic waters that flow along the coast are less dense (with densities slightly underestimated as compared to in situ measurements; Beuvier, 2011) and therefore strongly isolated from the rest of the water column. As a result, their nutrient content will be progressively consumed and these waters become more and more oligotrophic as they flow along the southern coast of the basin, and always remain more oligotrophic than the rest of the eastern basin. In summer and autumn, they can even be considered ultraoligotrophic (see the phytoplankton $Q_{\mathrm{P}}$ in Fig. 10c and d). Moreover, they extend over a layer of around $100 \mathrm{~m}$ in thickness in which concentrations are roughly homogeneous. During summer and autumn, bacteria are also strongly P-limited but more and more carbon-rich (see Fig. 11) since phytoplankton exudation still proceeds (though at extremely low rates in autumn). Moreover, the vertical mixing that starts in autumn is not sufficiently deep to reach the nutrient-rich waters since the mixed layer depth (MLD) is shallower than the bottom of these Atlantic waters. In addition, since DOC concentration is high over the whole layer, DOC surface concentrations are not diluted by the mixing. As a result, accumu- lation still proceeds until winter, during which higher mixed layer depth will allow the $\mathrm{P}$ enrichment in surface waters and dilute surface DOC concentrations as well.

Furthermore, DOC concentrations (as well as DOC annual export flux, though this is more difficult to see in Fig. 5) are negligible throughout the year in some well-identified regions, namely the two cyclonic structures in the Tyrrhenian Sea, the south of the Adriatic Sea (excluding the coastal zones), and the region of the Rhodes Gyre in the Levantine Basin. All these structures are characterized by regular input of nutrients from deep waters, resulting in an absence of strong $\mathrm{P}$ limitation in bacteria. Under such conditions, the bacteria carbon quota is rather low and DOC accumulation and export cannot occur.

Finally, the strong link between low phosphate availability in the upper surface water of the Mediterranean Sea and DOC accumulation due to nutrient limitation of bacterial production that is evidenced in this modeling study is consistent with previous in situ (Moutin et al., 2002; Van Wambeke et al., 2002) and modeling (Thingstad et al., 1997) studies and is shown to apply at the scale of the whole of the Mediterranean Sea, with the exception of the aforementioned specific regions.

\subsection{Robustness of results}

Though difficult to achieve in a rigorous way, the robustness of our main results will be discussed in the following section. As shown in section (Sect. 2.2), the model includes many DOC and POC production and consumption processes. A sensitivity study on all the parameters they involve is obviously impossible to achieve, though some steps towards this goal have already been made in Baklouti et al. (2006b). Moreover, accounting for the fact that most of the parameters used have a physiological significance (including cell size considerations) and constitute a coherent set that remains unchanged for the different studies undertaken with Eco3M-MED (even outside the Mediterranean), we consider that their values are reasonably reliable. However, the POC to DOC degradation (i.e., hydrolysis) rate and the sinking velocity are not physiological parameters and their impact on the results will be discussed later.

The comparison of DOC stocks with the few available results (see the Supplement) showed that, though the shape of the modeled DOC vertical profiles was quite different (but the values were on the same order of magnitude) from those measured, modeled and measured integrated DOC stocks over the $0-100 \mathrm{~m}$ layer showed much better agreement. Furthermore, when compared to in situ estimations of DOC export from the DyFaMed station (Avril, 2002) and the Adriatic and Tyrrhenian seas (Santinelli et al., 2013), the model always provides higher DOC export values. These differences in DOC export may be partly attributable to the model failures discussed in the Supplement, but, as already mentioned, in situ estimations also involve considerable uncer- 
tainties. Hence, according to Santinelli et al. (2013), DOC export computations from stock differences below the euphotic layer probably underestimate the real flux. This is also the conclusion we came to by using model outputs to compute export fluxes with our method and with the in situ method. If we assume, however, that the different in situ estimations are consistent with each other, it appears that the highest DOC export occurs in the Adriatic Sea, followed by the DyFaMed station (Ligurian Sea) and then by the Tyrrhenian Sea, and the same order can be inferred from the model outputs.

Two parameters are essential in POC export, namely POC to DOC degradation rate and the sinking velocity.

Since our model includes a single detrital compartment, an intermediate value of $2 \mathrm{~m} \mathrm{~d}^{-1}$ has been used for the sinking velocity. This value is intended to be representative of the high sinking rates $\left(>100 \mathrm{~m} \mathrm{day}^{-1}\right)$ of very large particles as well as the very low sinking rates of small particles. It may, however, reflect an underestimation of the actual mean value, though this is difficult to verify. In several other models (e.g., Lévy et al., 1998; Lacroix and Gregoire, 2002; Herrmann and Somot, 2008), two detrital compartments are used, thus making it possible to differentiate between low and high sinking rates of detrital particles. However, in these models, the large detrital compartment (i.e., the one associated with high sinking rates) is only fueled by zooplankton fecal pellets (Lévy et al., 1998; Herrmann and Somot, 2008) and by mesozooplankton mortality in Lacroix and Gregoire (2002). These fluxes, except the latter, are probably weak compared to the other POC sources in our model (which is dominated by the mortality of the largest organisms). Finally, in these models, the remaining sources of POC fuel the small detrital compartment for which the sinking velocities are lower than that used in our model. To conclude on this point, adding complexity in a given model generally leads to the multiplication of the number of state variables and parameters. When these parameters and/or these new processes are not well known, this also adds uncertainty, and in this case complexity does not necessarily lead to a better agreement between model outputs and observations as is suggested by several studies (e.g., Muller et al., 2009; Kriest et al., 2010; Paudel and Jawitz, 2012). With the addition of a class of large detrital particles, the sinking velocity associated with this detrital compartment as well as the definition of the processes that would have fueled this additional compartment (the latter are not the same in the different aforementioned models that use two detrital compartments) would have added a source of uncertainty in the model. As a consequence, the particulate carbon fluxes would not necessarily have been more realistic than the ones provided by this study. The same conclusion may apply as regards the aggregation models whose formulations are generally empirical and associated with parameters that are hardly measurable.

More importantly, it can be considered that the likely underestimated sinking velocity used in the present model is compensated for by the very low POC degradation rate. In our model, its maximum value is set at $0.03 \mathrm{~d}^{-1}$ but it is modulated by the bacteria carbon quota. In substance, the higher the carbon quota, the more the degradation rate decreases, and eventually it becomes 0 when the bacteria carbon quota is maximum. As a result, the effective POC degradation rate is always less than $0.03 \mathrm{~d}^{-1}$ in the model, and it is lower in the surface layers since bacteria are more rich in carbon than in deep waters. It is also lower than all the values used in the aforementioned models. Concerning in situ data for the degradation rate, Sempéré et al. (2000) determined values at 50 and $200 \mathrm{~m}$ for labile and less labile POC in three regions of the Mediterranean Sea, showing that, for the labile POC (which represent a significant part in the latter study), the degradation rate can be up to 100 times higher than that used in the present study.

Apart from these two parameters, it has been shown that the model underestimates Chl concentrations at the DCM (mainly due to a lack of large phytoplankton) and this may also lead to an underestimation of POC export. However, the 0-100 m mIPP values are consistent with oIPP, thereby suggesting that this DCM underestimation has only a limited impact on carbon production. Overall, the annual POC export flux at $100 \mathrm{~m}$ provided by the model is around $8 \%$ of the annual primary production, a value that is consistent with in situ estimations (Miquel et al., 1994).

Between 100 and $200 \mathrm{~m}$, however, the mean bacteria carbon quota is lower since POC hydrolysis and bacteria and heterotrophic nanoflagellate mortalities are the only sources of DOC, resulting in higher hydrolysis rates and in lower POC export at $200 \mathrm{~m}$. Looking at the vertical attenuation of POC fluxes, it is common to use a power law expressed as $F(z)=F\left(z=z_{0}\right) \times\left(\frac{z}{z_{0}}\right)^{-b}$, where $F(z)$ is the depthdependent POC flux and $b$ a positive coefficient whose values may vary according to the location or the period. In regions of significant export, $b$ values inferred from the model outputs fluctuate between 0.9 in the Provencal sub-basin and 2.3 for the Algerian Basin. Values of $b$ derived from observations tend to be lower, i.e., respectively equal to 0.92 and 1.0 for the western and eastern moorings (Gogou et al., 2014), or 0.75 in the Alboran Sea (Zúñiga et al., 2007). This again suggests that the attenuation of POC export flux between 100 and $200 \mathrm{~m}$ is too great in the model. Furthermore, when compared to the few available data for POC export fluxes, the model always underestimates the export flux in the eastern basin. However, all the in situ estimations we could find in the literature were done at 150 or $200 \mathrm{~m}$ depth, which means in the 100-200 m layer, where the modeled POC export is more likely to be underestimated. In summary, all this suggests that the underestimation of POC export fluxes is more likely to be the case at 200 than at $100 \mathrm{~m}$ depth, though the comparison at the DyFaMed station shows that the mean mPOC export rate $\left(5.6\right.$ and $2.2 \mathrm{gC} \mathrm{m}^{-2} \mathrm{yr}^{-1}$ at 100 and $200 \mathrm{~m}$ respectively) is within the range of the measured rate at $200 \mathrm{~m}$ (i.e., [1.6;2.6] $\mathrm{gC} \mathrm{m}^{-2} \mathrm{yr}^{-1}$; Copin-Montégut 
and Avril, 1993; Miquel et al., 2011). Finally, it is very unlikely that these uncertainties could shed doubt on the predominance of DOC in the OC export in the eastern basin. This conclusion also applies in the western basin (though with less certainty), all the more so in that in situ measurements allow the same conclusion to be drawn in the sampled stations of the NW Mediterranean (Copin-Montégut and Avril, 1993; Avril, 2002; Miquel et al., 2011).

\section{Conclusions}

A 14-year simulation combining a high-resolution physical model (NEMO-MED12) and a mechanistic biogeochemical model (Eco3M-MED) has been developed to study carbon organic production and fate at the scale of the Mediterranean Sea.

A preliminary work presented in the Supplement focused on the model skill assessment through an extensive comparison of different model outputs (i.e., chlorophyll, nutrients, primary production and DOC profiles) with available data at various time and space scales. This work allowed for verification of the model's ability to represent the main features of the biogeochemical functioning of the Mediterranean Sea. In the Results section, carbon export fluxes are investigated. Previous estimations of DOC export in the Mediterranean Sea were restricted to specific regions of the Mediterranean (e.g., the Ligurian, Adriatic, Tyrrhenian seas). We here propose the first Mediterranean-scale view of annual DOC and POC export fluxes, as well as an analysis of their spatial and seasonal variations in light of plankton intracellular quotas.

The two major results of this modeling study lie in (i) the predominance of the eastern basin in OC export (with nearly $60 \%$ of the OC export occurring in the eastern basin) and (ii) in the crucial role of the dissolved fraction in the total organic carbon export. At Mediterranean scale, DOC export represents about four-fifths of total organic carbon fluxes, thereby attesting to its major role in the carbon cycle and the biological pump in the Mediterranean Sea. The concept of a malfunctioning microbial loop (Thingstad et al., 1997), due to high P limitation of both phytoplankton and bacteria leading to high DOC exudation fluxes beyond bacterial needs, also applies in the present study though it is generalized to the whole of the Mediterranean Basin, except for some specific P-rich regions (see Results and Discussion). Export in the eastern basin is markedly high despite its lower productivity compared to the western basin. By contrast, POC export is closely associated with regions characterized by high productivity. As a consequence, total carbon export in the eastern basin is considerably higher than expected as regards its low primary productivity. Results also show high spatial variability in organic carbon fluxes and a temporal uncoupling between POC and DOC exports. This is attributable to the differences in the processes involved in the production and export of POC and DOC.
Further comparisons with observations are clearly necessary to confirm these results, which emphasizes the need for in situ temporal monitoring to properly quantify organic carbon export. This study also highlights the need to examine the microbial food web in detail in order to further investigate the carbon cycle in the Mediterranean Sea. Furthermore, the implementation of an explicit inorganic carbon compartment in the biogeochemical model would close the carbon budget and help in the full characterization of the biological pump.

In conclusion, the strong link between low phosphate availability in the upper surface water of the Mediterranean Sea and DOC accumulation due to nutrient limitation of bacterial production already identified by previous modeling (Thingstad et al., 1997) and in situ (Moutin et al., 2002; Van Wambeke et al., 2002) studies is confirmed by this modeling study, which may therefore be of interest for other oceanic regions. The low phosphate availability of the upper waters has been identified in other oceanic regions such as the Sargasso Sea (Wu et al., 2000), the North Pacific and the southwest Pacific (Van Den Broeck et al., 2004), and high DOC accumulation has also been reported in some of these areas (Carlson et al., 1994). This work may therefore be of interest for these oceanic regions. Finally, in the context of climate change, the enhanced stratification and the probable geographical extension of low phosphate availability in upper waters (Karl et al., 1997; Moutin et al., 2008) is expected to result in an increase in DOC production (Santinelli et al., 2013; Lazzari et al., 2013) and thereby further increase the importance of DOC in the biological carbon pump.

\section{The Supplement related to this article is available online at doi:10.5194/bg-12-7025-2015-supplement.}

Acknowledgements. The authors are grateful to the various organizations that funded this work. This includes the French PACA region (which funded the $\mathrm{PhD}$ thesis of A. Guyennon), the Mercator Ocean group (which funded the SiMED project that provided an efficient framework for this work), the MED-ICCBIO project (funded by the Groupement d' Intérêt Scientifique "Climat, Environnement et Société"), and the OT-MED Labex. This work is a contribution to the Labex OT-Med (no. ANR-11-LABEX-0061) funded by the French Government "Investissements d'Avenir" program of the French National Research Agency (ANR) through the A*MIDEX project (no. ANR-11-IDEX-0001-02). It is also a contribution to the MerMEx-MISTRALS program, and access was granted to the HPC resources of IDRIS (Institut du Développement et des Ressources en Informatique Scientifique) of the Centre National de la Recherche Scientifique (CNRS). The DYFAMED time series was provided by the Oceanological Observatory (CNRS-UPMC) of Villefranche-sur-Mer (L. Coppola). This project is funded by CNRS-INSU and ALLENVI through the MOOSE observation network. The satellite data used in this is study are MyOcean products. The authors are also grateful to Jean-Michel 
André for his help and valuable advice, to L. Coppola for his very efficient assistance in obtaining in situ data from the DyFaMed station, to Meteo-France/CNRM for running and providing the ARPERA data set and to Antoine Mangin (Société ACRI Sophia-Antipolis, France).

Edited by: C. Heinze

\section{References}

Alekseenko, E., Raybaud, V., Espinasse, B., Carlotti, F., Queguiner, B., Thouvenin, B., Garreau, P., and Baklouti, M.: Seasonal dynamics and stoichiometry of the planktonic community in the NW Mediterranean Sea: a 3D modeling approach, Ocean Dynam., 64, 179-207, 2014.

Avril, B.: DOC dynamics in the northwestern Mediterranean Sea (DYFAMED site), Deep-Sea Res. Pt. II, 49, 2163-2182, 2002.

Baklouti, M., Diaz, F., Pinazo, C., Faure, V., and Quéguiner, B.: Investigation of mechanistic formulations depicting phytoplancton dynamics for models of marine pelagic ecosystems and description of a new model, Prog. Oceanogr., 71, 1-33, 2006a.

Baklouti, M., Faure, V., Pawlowski, L., and Sciandra, A.: Investigation and sensitivity analysis of a mechanistic phytoplankton model implemented in a new modular numerical tool (Eco3M) dedicated to biogeochemical modelling, Prog. Oceanogr., 71, 34-58, 2006b.

Baklouti, M., Chevalier, C., Bouvy, M., Corbin, D., Pagano, M., Troussellier, M., and Arfi, R.: A study of plankton dynamics under osmotic stress in the Senegal River Estuary, West Africa, using a 3D mechanistic model, Ecol. Model., 222, 2704-2721, 2011.

Baretta, J., Ebenhoh, W., and Ruardij, P.: The European Regional Seas Ecosystem Model, a complex marine ecosystem model, J. Sea Res., 33, 233-246, 1995.

Béranger, K., Mortier, L., and Crépon, M.: Seasonal variability of water transport through the Straits of Gibraltar, Sicily and Corsica, derived from a high-resolution model of the Mediterranean circulation, Prog. Oceanogr., 66, 341-364, 2005.

Bertilsson, S., Berglund, O., Karl, D. M., and Chisholm, S. W.: Elemental composition of marine Prochlorococcus and Synechococcus: Implications for the ecological stoichiometry of the sea, Limnol. Oceanogr., 48, 1721-1731, 2003.

Beuvier, J.: Modélisation de la variabilité climatique de la circulation et des masses d'eau en mer Méditerranée: impact des échanges océan-atmosphére, $\mathrm{PhD}$ thesis, Ecole Polytechnique, Paris, France, 256 pp., 2011.

Beuvier, J., Sevault, F., Herrmann, M., Kontoyiannis, H., Ludwig, W., Rixen, M., Stanev, E., Béranger, K., and Somot, S.: Modeling the Mediterranean Sea interannual variability during 1961-2000: focus on the Eastern Mediterranean Transient, J. Geophys. Res.Oceans, 115, C08017, doi:10.1029/2009JC005950, 2010.

Beuvier, J., Lebeaupin-Brossier, C., Béranger, K., Arsouze, T., BourdalléBadie, R., Deltel, C., Drillet, Y., Drobinski, P., Lyard, F., Ferry, N., Sevault, F., and Somot, S.: Spreading of the Western Mediterranean Deep Water after winter 2005: Time scales and deep cyclone transport, J. Geophys. Res., 117, C07022, doi:10.1029/2011JC007679, 2012a.
Beuvier, J., Lebeaupin-Brossier, C., Béranger, K., Arsouze, T., Bourdallé-Badie, R., Deltel, C., Drillet, Y., Drobinski, P., Lyard, F., Ferry, N., Sevault, F., and Somot, S.: Oceanic component for the modeling of the regional Mediterranean Eart System., Mercator Ocean Quarterly Newsletter, 46, 60-66, 2012b.

Boldrin, A., Miserocchi, S., Rabitti, S., Turchetto, M., Balboni, V., and Socal, G.: Particulate matter in the southern Adriatic and Ionian Sea: characterisation and downward fluxes, J. Marine Syst., 33, 389-410, 2002.

Bopp, L., Monfray, P., Aumont, O., Dufresne, J., Le Treut, H., Madec, G., Terray, L., and Orr, J.: Potential climate change on marine export production, Global Biogeochem. Cy., 15, 81-99, 2001.

Bosc, E., Bricaud, A., and Antoine, D.: Seasonal and interannual variability in algal biomass and primary production in the Mediterranean Sea, as derived from 4 years of SeaWiFS observations, Global Biogeochem. Cy., 18, GB1005, doi:10.1029/2003GB002034, 2004.

Brown, E. J. and Harris, R. F.: Kinetics of algal transient phosphate uptake and the cell quota concept, Limnol. Oceanogr., 23, 35-40, 1978.

Buesseler, K.: Do upper-ocean sediment traps provide an accurate record of particle flux?, Nature, 353, 420-423, 1991.

Carlson, C., Ducklow, H., and Michaels, A.: Annual flux of dissolved organic carbon from the euphotic zone in the northwestern Sargasso Sea, Nature, 371, 405-408, 1994.

Christaki, U., Courties, C., Joux, F., Jeffrey, W. H., Neveux, J., and Naudin, J.: Community structure and trophic role of ciliates and heterotrophic nanoflagellates in Rhone River diluted mesoscale structures (NW Mediterranean Sea), Aquat. Microb. Ecol., 57, 263-277, 2009.

Claustre, H., Morel, A., Hooker, S., Babin, M., Antoine, D., Oubelkheir, K., Bricaud, A., Leblanc, K., Queguiner, B., and Maritorena, S.: Is desert dust making oligotrophic waters greener?, Geophys. Res. Lett., 29, 107-1-107-4, 2002.

Copin-Montégut, G. and Avril, B.: Vertical distribution and temporal variation of dissolved organic carbon in the North-Western Mediterranean Sea, Deep-Sea Res. Pt. I, 40, 1963-1972, 1993.

Crise, A., Crispi, G., and Mauri, E.: A seasonal three-dimensional study of the nitrogen cycle in the Mediterranean Sea: Part I. Model implementation and numerical results, J. Marine Syst., 18, 287-312, 1998.

Crispi, G., Crise, A., and Solidoro, C.: Three-dimensional oligotrophic ecosystem models driven by physical forcing: the Mediterranean Sea case, Environ. Modell. Softw., 13, 483-490, 1998.

Diaz, F., Raimbault, P., Boudjellal, B., Garcia, N., and Moutin, T.: Early spring phosphorus limitation of primary productivity in a NW Mediterranean coastal zone (Gulf of Lions), Mar. Ecol.Prog. Ser., 211, 51-62, 2001.

D’Ortenzio, F., Marullo, S., Ragni, M., Ribera d'Alcalà, M., and Santoleri, R.: Validation of empirical SeaWiFS algorithms for chlorophyll-a retrieval in the Mediterranean Sea: A case study for oligotrophic seas, Remote Sens. Environ., 82, 79-94, 2002.

Droop, M.: Vitamin B12 and marine ecology. IV. The kinetics of uptake, growth and inhibition in Monochrysis lutheri, J. Mar. Biol. Assoc. UK, 48, 689-733, 1968

Droop, M.: The nutrient status of algal cells in batch culture, J. Mar. Biol. Assoc. UK, 55, 541-555, 1975. 
Eppley, R. and Peterson, B.: Particulate organic matter flux and planktonic new production in the deep ocean, Nature, 282, 677680, 1979.

Fasham, M., Flynn, K., Pondaven, P., Anderson, T., and Boyd, P.: Development of a robust marine ecosystem model to predict the role of iron in biogeochemical cycles: A comparison of results for iron-replete and iron-limited areas, and the SOIREE ironenrichment experiment, Deep-Sea Res. Pt. I, 53, 333-366, 2006.

Fukuda, R., Ogawa, H., Nagata, T., and Koike, I.: Direct Determination of Carbon and Nitrogen Contents of Natural Bacterial Assemblages in Marine Environments, Appl. Environ. Microb., 64, 3352-3358, 1998.

Garcia, H. E., Locarnini, R., Boyer, T., and Antonov, J.: World Ocean Atlas 2005, Vol. 4, Nutrients (phosphate, nitrate, silicate), 2006.

Geider, R., MacIntyre, H., and Kana, T.: A dynamic regulatory model of phytoplankton acclimation to light, nutrients, and temperature, Limnol. Oceanogr., 43, 679-694, 1998.

Gogou, A., Sanchez-Vidal, A., Durrieu de Madron, X., Stavrakakis, S., Calafat, A. M., Stabholz, M., Psarra, S., Canals, M., Heussner, S., Stavrakaki, I., and Papathanassiou, E.: Carbon flux to the deep in three open sites of the Southern European Seas (SES), J. Marine Syst., 129, 224-233, 2014.

Gómez, F.: The role of the exchanges through the Strait of Gibral$\operatorname{tar}$ on the budget of elements in the Western Mediterranean Sea: consequences of human-induced modifications, Mar. Pollut. Bull., 46, 685-694, 2003.

Hansell, D. and Carlson, C.: Marine Dissolved Organic Matter and the Carbon Cycle, Oceanography, 14, 685-716, 2001.

Hansell, D., Carlson, C., and Suzuki, Y.: Dissolved organic carbon export with North Pacific Intermediate Water formation, Global Biogeochem. Cy., 16, 7-1-7-8, 2002.

Hansell, D., Repeta, D., Carlson, C., and Schlitzer, R.: Dissolved organic matter in the ocean: A controversy stimulates new insights, Oceanography, 22, 202-211, 2009.

Heldal, M., Scanlan, D. J., Norland, S., Thingstad, F., and Mann, N. H.: Elemental composition of single cells of various strains of marine Prochlorococcus and Synechococcus using X-ray microanalysis, Limnol. Oceanogr., 48, 1732-1743, 2003.

Herrmann, M. and Somot, S.: Relevance of ERA40 dynamical downscaling for modeling deep convection in the Mediterranean Sea, Geophys. Res. Lett., 35, L04802, doi:10.1029/2007GL032442, 2008.

Herrmann, M., Diaz, F., Estournel, C., Marsaleix, P., and Ulses, C.: Impact of atmospheric and oceanic interannual variability on the Northwestern Mediterranean Sea pelagic planktonic ecosystem and associated carbon cycle, J. Geophys. Res.-Oceans, 118, 5792-5813, 2014.

Holling, C.: Some characteristics of simple types of predation and parsitism, The Candian Entomologist, 91, 385-398, 1959.

Karl, D. M., Letelier, R. M., Tupas, L., Dore, J., Christian, J., and Hebel, D.: The role of nitrogen fixation in biogeochemical cycling in the subtropical North Pacific Ocean, Nature, 387, 533538, 1997.

Klausmeier, C., Litchman, E., and Levin, S.: Phytoplankton growth and stoichiometry under multiple nutrient limitation, Limnol. Oceanogr., 49, 1463-1470, 2004.

Klausmeier, C., Litchman, E., Daufresne, T., and Levin, S.: Phytoplankton stoichiometry, Ecol. Res., 23, 479-485, 2008.
Kooijman, S. A. L. M.: Dynamic Energy and Mass Budgets in Biological Systems, Cambridge University Press, Cambridge, UK, 2000.

Kriest, I., Khatiwala, S., and Oschlies, A.: Towards an assessment of simple global marine biogeochemical models of different complexity, Prog. Oceanogr., 86, 337-360, 2010.

Lacroix, G. and Gregoire, M.: Revisited ecosystem model (MODECOGeL) of the Ligurian Sea: seasonal and interannual variability due to atmospheric forcing, J. Marine Syst., 37, 229-258, 2002.

Lazzari, P., Mattia, G., Solidoro, C., Salon, S., Crise, A., Zavatarelli, M., Oddo, P., and Vichi, M.: The impacts of climate change and environmental management policies on the trophic regimes in the Mediterranean Sea: Scenario analyses, J. Marine Syst., 135, 137149, 2013.

Leblanc, K., Quéguiner, B., Garcia, N., Rimmelin, P., and Raimbault, P.: Silicon cycle in the NW Mediterranean Sea: seasonal study of a coastal oligotrophic site, Oceanol. Acta, 26, 339-355, 2003.

Lefèvre, D., Denis, M., Lambert, C., and Miquel, J.: Is DOC the main source of organic matter remineraliztion in the ocean water column?, J. Marine Syst., 7, 281-291, 1996.

Le Quéré, C. L., Harrison, S., P., C., Buitenhuis, E., Aumont, O., Bopp, L., Claustre, H., Cotrim Da Cunha, L., Geider, R., Giraud, X., Klaas, C., Kohfeld, K. E., Legendre, L., Manizza, M., Platt, T., Rivkin, R. B., Sathyendranath, S., Uitz, J., Watson, A. J., and Wolf-Gladrow, D.: Ecosystem dynamics based on plankton functional types for global ocean biogeochemistry models, Glob. Change Biol., 11, 2016-2040, 2005.

Le Quéré, C., Takahashi, T., Buitenhuis, E., Rödenbeck, C., and Sutherland, S.: Impact of climate change and variability on the global oceanic sink of $\mathrm{CO}_{2}$, Global Biogeochem. Cy., 24, 20162040, 2010.

Lévy, M., Mémery, L., and André, J.: Simulation of primary production and export fluxes in the Northwestern Mediterranean Sea, J. Mar. Res., 56, 197-238, 1998.

Lovdal, T., Skjoldal, E. F., Heldal, M., Norland, S., and Thingstad, T. F.: Changes in morphology and elemental composition of Vibrio splendidus along a gradient from carbon-limited to phosphate-limited growth, Microb. Ecol., 55, 152-161, 2008.

Ludwig, W.: Continental erosion and river transport of organic carbon to the world's Oceans, $\mathrm{PhD}$ thesis, Université Louis Pasteur de Strasbourg, Strasbourg, France, 1996.

Ludwig, W., Dumont, E., Meybeck, M., and Heussner, S.: River discharges of water and nutrients to the Mediterranean and Black Sea: Major drivers for ecosystem changes during past and future decades?, Prog. Oceanogr., 80, 199-217, 2009.

Macías, D., Stips, A., and Garcia-Gorriz, E.: The relevance of deep chlorophyll maximum in the open Mediterranean Sea evaluated through 3D hydrodynamic-biogeochemical coupled simulations, Ecol. Model., 281, 26-37, 2014.

Madec, G. and the NEMO team: NEMO ocean engine, Note du pole de modélisation de l'IPSL, 27, 1228-1619, 2008.

Maier-Reimer, E., Mikolajewicz, U., and Winguth, A.: Future ocean uptake of $\mathrm{CO}_{2}$ : interaction between ocean circulation and biology, Clim. Dynam., 12, 711-722, 1996.

Marshall, J. and Schott, F.: Open-ocean convection: Observations, theory, and models, Rev. Geophys., 37, 1-64, 1999. 
Marty, J. C. and Chiavérini, J.: Hydrological changes in the Ligurian Sea (NW Mediterranean, DYFAMED site) during 1995-2007 and biogeochemical consequences, Biogeosciences, 7, 21172128, doi:10.5194/bg-7-2117-2010, 2010.

Marty, J.-C., Garcia, N., and Raimbault, P.: Phytoplankton dynamics and primary production under late summer conditions in the NW Mediterranean Sea, Deep-Sea Res. Pt. I, 55, 1131-1149, 2008.

Mattia, G., Zavatarelli, M., Vichi, M., and Oddo, P.: The Eastern Mediterranean Sea biogeochemical dynamics in the 1990s: A numerical study, J. Geophys. Res.-Oceans, 118, 2231-2248, 2013.

Mauriac, R., Moutin, T., and Baklouti, M.: Accumulation of DOC in Low Phosphate Low Chlorophyll (LPLC) area: is it related to higher production under high $\mathrm{N}: \mathrm{P}$ ratio?, Biogeosciences, 8 , 933-950, doi:10.5194/bg-8-933-2011, 2011.

Meador, T., Gogou, A., Spyres, G., Herndl, G., Krasakopoulou, E., Psarra, S., Yokokawa, T., De Corte, D., Zervakis, V., and Repeta, D.: Biogeochemical relationships between ultrafiltered dissolved organic matter and picoplankton activity in the Eastern Mediterranean Sea, Deep-Sea Res. Pt. II, 57, 1460-1477, 2010.

Millot, C. and Taupier-Letage, I.: Circulation in the Mediterranean sea, in: The Mediterranean Sea, Springer, Berlin, Heidelberg, 29-66, 2005.

Miquel, J., Martín, J., Gasser, B., Rodriguez-y Baena, A., Toubal, T., and Fowler, S.: Dynamics of particle flux and carbon export in the northwestern Mediterranean Sea: a two decade timeseries study at the DYFAMED site, Prog. Oceanogr., 91, 461481,2011

Miquel, J. C., Fowler, S. W., La Rosa, J., and Buat-Menard, P.: Dynamics of the downward flux of particles and carbon in the open northwestern Mediterranean Sea, Deep-Sea Res. I, 41, 243-261, 1994.

Moore, J. K., Doney, S. C., Kleypas, J. A., Glover, D. M., and Fung, I. Y.: An intermediate complexity marine ecosystem model for the global domain, Deep-Sea Res. Pt. II, 49, 403-462, 2002.

Morel, A.: Optical modeling of the upper ocean in relation to its biogenous matter content (case I waters), J. Geophys. Res.Oceans, 93, 10749-10768, 1988

Moutin, T. and Raimbault, P.: Primary production, carbon export and nutrients availability in Western and Eastern Mediterranean Sea in early summer 1996 (MINOS cruise), J. Marine Syst., 33, 273-288, 2002.

Moutin, T., Thingstad, T. F., Van Wambeke, F., Marie, D., Slawyk, G., and Raimbault, P.: Does competition for nanomolar phosphate supply explain the predominance of the cyanobacterium Synechococcus?, Limnol. Oceanogr., 47, 1562-1567, 2002.

Moutin, T., Karl, D. M., Duhamel, S., Rimmelin, P., Raimbault, P., Van Mooy, B. A. S., and Claustre, H.: Phosphate availability and the ultimate control of new nitrogen input by nitrogen fixation in the tropical Pacific Ocean, Biogeosciences, 5, 95-109, doi:10.5194/bg-5-95-2008, 2008.

Moutin, T., Van Wambeke, F., and Prieur, L.: Introduction to the Biogeochemistry from the Oligotrophic to the Ultraoligotrophic Mediterranean (BOUM) experiment, Biogeosciences, 9, 38173825, doi:10.5194/bg-9-3817-2012, 2012.

Muller, S., Muñoz-Carpena, R., and Kiker, G.: Model Relevance: Frameworks for Exploring the Complexity-SensitivityUncertainty Trilemma, in: Climate: Global Change and Local
Adaptation, edited by: Linkov, I. and Bridges, T. S., Springer, Dordrecht, 2009.

Palmiéri, J.: Modélisation biogéochimique de la mer Méditerranée avec le modèle régional couplé NEMO-MED12/PISCES., PhD thesis, Université de Versailles Saint-Quentin, France, 2014.

Palmiéri, J., Le Vu, B., Dutay, J., Bopp, L., Béranger, K., Beuvier, J., Somot, S., and Éthé, C.: Biogeochemical modelling of the Mediterranean Sea with PISCES MED-12 model, Geosci. Model Dev., in preparation, 2015.

Pasqueron de Fommervault, O., Migon, C., D’Ortenzio, F., Ribera d'Alcalà, M., and Coppola, L.: Temporal variability of nutrient concentrations in the northwestern Mediterranean sea (DYFAMED time-series station), Deep-Sea Res. Pt. I, 100, 1-12, 2015.

Paudel, R. and Jawitz, J.: Does increased model complexity improve description of phosphorus dynamics in a large treatment wetland?, Ecol. Eng., 42, 283-294, 2012.

Prowe, A., Pahlow, M., Dutkiewicz, S., Follows, M., and Oschlies, A.: Top-down control of marine phytoplankton diversity in a global ecosystem model, Prog. Oceanogr., 101, 1-13, 2012.

Redfield, A. C.: The biological control of chemical factors in the environment, Am. Sci., 46, 205-221, 1958.

Rixen, M., Beckers, J. M., Levitus, S., Antonov, J., Boyer, T., Maillard, C., Fichaut, M., Balopoulos, E., Iona, S., Dooley, H., Garcia, M. J., Manca, B., Giorgetti, A., Manzella, G., Mikhailov, N., Pinardi, N., Zavatarelli, M., and the Medar Consortium: The western mediterranean deep water : a proxy for climate change, Geophys. Res. Lett., 32, L12608, doi:10.1029/2005GL022702, 2005

Santinelli, C., Hansell, D. A., and d'Alcala M., R.: Influence of stratification on marine dissolved organic carbon (DOC) dynamics : The Mediterranean Sea case, Prog. Oceanogr., 119, 68-77, 2013.

Sarmiento, J. and Gruber, N.: Ocean biogeochemical dynamics, vol. 1015, Princeton University Press, Princeton, USA, 528 pp., 2006

Sarmiento, J., Hughes, T., Stouffer, R., and Manabe, S.: Simulated response of the ocean carbon cycle to anthropogenic climate warming, Nature, 393, 245-249, 1998.

Schaap, D. and Lowry, R.: SeaDataNet-Pan-European infrastructure for marine and ocean data management: unified access to distributed data sets, International Journal of Digital Earth, 3, 50 69, 2010

Sempéré, R., Yoro, S. C., Van Wambeke, F., and Charrière, B.: Microbial decomposition of large organic particles in the Northwestern Mediterranean Sea: an experimental approach, Mar. Ecol.-Prog. Ser., 198, 61-72, 2000.

Siegenthaler, U. and Sarmiento, J.: Atmospheric carbon dioxide and the ocean, Nature, 365, 119-125, 1993.

Siokou-Frangou, I., Christaki, U., Mazzocchi, M. G., Montresor, M., Ribera d'Alcalá, M., Vaqué, D., and Zingone, A.: Plankton in the open Mediterranean Sea: a review, Biogeosciences, 7, 1543 1586, doi:10.5194/bg-7-1543-2010, 2010.

Somot, S., Sevault, F., and Déqué, M.: Transient climate change scenario simulation of the Mediterranean Sea for the twenty-first century using a high-resolution ocean circulation model, Clim. Dynam., 27, 851-879, 2006.

Talarmin, A., Van Wambeke, F., Duhamel, Catala, P., Moutin, T., and Lebaron, P.: Improved methodology to measure taxonspecific phosphate uptake in live and unfiltered samples, Lim- 
nol. Oceanogr.-Meth., 9, 443-453, doi:10.4319/lom.2011.9.443, 2011.

Thingstad, T., Hagström, A., and Rassoulzadegan, F.: Accumulation of degradable DOC in surface waters: Is it caused by a malfunctioning microbial loop?, Limnol. Oceanogr., 42, 398-404, 1997.

Thingstad, T., Krom, M., Mantoura, R., Flaten, G., Groom, S., Herut, B., Kress, N., Law, C., Pasternak, A., Pitta, P., Psarra, S., Rassoulzadegan, F., Tanaka, T., Tselepides, A., Wassman, P., Woodward, E., Wexels, R., Zodiatis, G., and Zohary, T.: Nature of phosphorus limitation in the ultraoligotrophic eastern Mediterranean, Science, 309, 1068-1071, 2005.

Toggweiler, J., Murmane, R., Carson, S., Gnanadesikan, A., and Sarmiento, J. L.: Representation of the carbon cycle in box models and GCMs: 2. Organic pump, Global Biogeochem. Cy., 17, 1027, doi:10.1029/2001GB001841, 2003.

Tugrul, S. and Besiktepe, S.: Nutrient exchange fluxes between the black sea and the Mediterranean through the turkish strait system (marmara sea, bosphorus and dardanelles), CIESM congress, Istanbul, Turkey, 0069, 2007.

Vallina, S., Ward, B., Dutkiewicz, S., and Follows, M.: Maximal feeding with active prey-switching: A kill-the-winner functional response and its effect on global diversity and biogeography, Prog. Oceanogr., 120, 93-109, 2014.

Van Den Broeck, N., Moutin, T., Rodier, M., and Le Bouteiller, A.: Seasonal variations of phosphate availability in the SW Pacific Ocean near New Caledonia, Mar. Ecol.-Prog. Ser., 268, 1-12, 2004.

Van Wambeke, F., Christaki, U., Giannakourou, A., Moutin, T., and Souvemerzoglou, K.: Longitudinal and vertical trends of bacterial limitation by phosphorus and carbon in the Mediterranean Sea, Microb. Ecol., 43, 119-133, 2002.
Vichi, M., Pinardi, N., and Masina, S.: A generalized model of pelagic biogeochemistry for the global ocean ecosystem. Part I: Theory, J. Marine Syst., 64, 89-109, 2007.

Volpe, G., Santoleri, R., Vellucci, V., Ribera d'Alcala, M., Marullo, S., and d'Ortenzio, F.: The colour of the Mediterranean Sea: Global versus regional bio-optical algorithms evaluation and implication for satellite chlorophyll estimates, Remote Sens. Environ., 107, 625-638, 2007.

Vörösmarty, C. J., Fekete, B., and Tucker, B. A.: River Discharge Database, Version 1.0 (RivDIS v1.0), Volumes 0 through 6, A contribution to IHP-V Theme 1, Technical Documents in Hydrology Series, UNESCO, Paris, 1996.

Wilhelm, S. W., King, A. L., Twining, B. S., LeCleir, G. R., DeBruyn, J. M., Strzepek, R. F., Breene, C. L., Pickmere, S., Ellwood, M. J., Boyd, P. W., and Hutchins, D. A.: Elemental quotas and physiology of a southwestern Pacific Ocean plankton community as a function of iron availability, Aquat. Microb. Ecol., 68, 185-194, 2013.

Wu, J., Sunda, W., Boyle, E., and Karl, D.: Phosphate depletion in the western North Atlantic Ocean, Science, 289, 759-762, 2000.

Zúñiga, D., Calafat, A., Sanchez-Vidal, A., Canals, M., Price, B., Heussner, S., and Miserocchi, S.: Particulate organic carbon budget in the open Algero-Balearic Basin (Western Mediterranean): Assessment from a one-year sediment trap experiment, Deep-Sea Res. Pt. I, 54, 1530-1548, 2007. 